[Vol. 130:416.

\title{
CONSTRUCTION LENDERS' LIABILITY TO CONTRACTORS, SUBCONTRACTORS, AND MATERIALMEN
}

\author{
CurTis R. REITZ $†$
}

The nature of private ordering, which lies at the heart of our idea of contract, necessarily implies that two parties deal with each other, in order to strike a bargain, by shaping their agreement. This is reflected in the traditional notion that contracts create rights and duties only for parties who are in privity with each other. ${ }^{1}$ This legal concept is no longer as well accepted as it once may have been. ${ }^{2}$

f Professor of Law, University of Pennsylvania. A.B. 1951, LL.B. 1956, University of Pennsylvania. The author gratefully acknowledges the research assistance of Gunther O. Carrle, J.D. 1980, University of Pennsylvania. An earlier version of this article was published as chapter nine of Construction Litrgation (K. Cushman ed. 1981).

1 Fundamental as it is to the idea of agreement, the notion of privity nevertheless does not feature in doctrinal statements about contract law in the United States. Historically, British law declares that a promise is unenforceable unless consideration moves from the promisee to the promisor. Dunlap Pneumatic Tyre Co. v. Selfridge \& Co., 1915 A.C. 847 (P.C.); A.G. GuEST, ANSON's LAw OF CoNTRACT 95-96 (25th ed. 1979); G.H. Treitel, THE LAw OF Contract 62-64 (5th ed. 1979). The effect of this doctrine is substantially to restrict contract disputes to persons who have bargained with each other.

The British view of consideration did not take hold in the United States. The 1932 Restatement explicitly rejected the privity aspect of consideration and this position is reaffirmed in the new Restatement: "The performance or return promise may be given to the promisor or to some other person. It may be given by the promisee or by some other person." RESTATEMENT (SECOND) OF Contracts $\$ 71(4)$ (1981). Without limits derived from consideration, American law has had to decide, using other doctrinal language, who may enforce a contractual promise. Privity concepts have not developed a single focus. Aspects of privity can be detected by inference in doctrines dealing with formation, modification, and discharge. More overt are the elements of privity in the law of agency (which some would characterize as independent of contracts) and of assignments. The aspect of contract law most commonly identified as dealing with matters of privity is the law relating to third party beneficiaries.

The Second Restatement includes the following illustration, pertinent to the subject of this Article, in its treatment of the law of third party beneficiaries: "A contracts to erect a building for $C$. $B$ then contracts with $A$ to supply lumber needed for the building. $C$ is an incidental beneficiary of $B$ 's promise [to supply lumber], and $B$ is an incidental beneficiary of $C$ 's promise to pay $A$ for the building." Restatement (Second) of Contracts $\$ 302$ illustration 19 (1981). Accord 4 A. Corbin, Corbin on Contracts $\$ 778$ (1951); see also Restatement of RestiTUTION \$110 (1937).

2 One major development, the right of "intended beneficiaries" to enforce contractual promises, is now well known in this country, Restatement (SECOND) of Contracts $\$ 302$ (I981), although scholars continue to seek a fully satisfying rationale for this position.

Another development relaxing privity requirements involved implied quality warranties in the sale of goods. Some persons remote from a seller have been 
In a number of transactional settings, courts have been willing to consider contract disputes despite lack of privity between the parties. This Article will consider one of these settings, suits against construction lenders by contractors, subcontractors, and materialmen.

Construction lending plays a vital role in private construction projects. $^{3}$ Developers typically provide a small fraction of the needed investment, and permanent lenders, secured by long-term mortgages, ordinarily do not extend credit until projects have been completed and begun operating. Construction lenders fill the shortterm credit needs of developers as construction projects proceed. When the project is finished, the construction lender is repaid from the proceeds of the permanent mortgage loan: A construction lender who does not intend to provide long-term credit will see to it that there is also a permanent mortgage "take-out" ${ }^{4}$ commitment at the outset.

A construction loan generally is committed before the project gets underway, and typically provides for payments to the developer in installments as the work progresses. Prudent lenders arrange the pay-out schedule so that the value of the work in place at any time exceeds the sums advanced by the lenders. As security for the loan, construction lenders take mortgages on the real property; thus, the

granted relief in such cases. The original breakthrough allowed persons who had suffered personal injuries from defective food or drink to sue the manufacturers, see, e.g., Jacob E. Decker \& Sons, Inc. v. Capps, 139 Tex. 609, 164 S.W.2d 828 (1942); Mazetti v. Armour \& Co., 75 Wash. 622, 135 P. 633 (1913), although some courts stoutly resisted this development, see, e.g., Chysky v. Drake Bros. Co., 235 N.Y. 468, 139 N.E. 576 (1923). In 1960, the Supreme Court of New Jersey widened the category of personal injury-implied warranty cases beyond food and drink. Henningsen v. Bloomfield Motors, Inc., 32 N.J. 358, 161 A.2d 69 (1960). In that same year, Prosser published a very influential article seeking to shift the basis of these personal injury cases from contract to tort. Prosser, The Assault Upon the Citadel (Strict Liability to the Consumer), 69 YALE L.J. 1099 (1960). Four years later, this view was advanced by the Restatement (Second) of Torts' inclusion of $\$ 402 \mathrm{~A}$. That provision has been enthusiastically embraced by state courts. See Reitz \& Seabolt, Warranties and Product Liability: Who Can Sue and Where?, 46 TEMPLE L.Q. 527 (1973). Acceptance of the new tort largely eclipsed the need for injured persons to seek a contract remedy, but strict tort liability, as defined by the Restatement, did not encompass economic loss. Courts have divided on the privity requirement in warranty claims for economic losses. Compare, e.g., Davis v. Homasote Co., 281 Or. 383, 574 P.2d 1116 (1978) (requiring privity) with Morrow v. New Moon Homes, Inc., 548 P.2d 279 (Alaska 1976) and Seely v. White Motor Co., 63 Cal. 2d 9, 403 P.2d 145, 45 Cal. Rptr. 17 (1965) and Santor v. A. \& M. Karagheusian, Inc., 44 N.J. 52, 207 A.2d 305 (1965) (not requiring privity).

3 Keenan, The Importance of Construction Lending, in Practising LAw INSTItute, Construction Luending 11 (1973).

4 A "take-out" commitment is a promise by a lender to make a long-term loan on the property when construction is completed by the developer. See G. OsBorne, G. Netson \& D. Whttman, Rear Estate Finance Law 721 (3d ed. 1979) [hereinafter cited as G. OsBonNe]. 
foreclosure value of the security effectively rises as the work proceeds toward completion.

If all goes well, the construction loan and the developer's investment together will be sufficient to pay the prime contractor, who in turn will pay subcontractors and materials suppliers, and so on down through lower tiers of suppliers of labor or materials. Unfortunately, in a great many instances all does not go well. The causes of construction project failures are many and varied, as are the circumstances that exist when work is halted. Frequently, in the wake of failure, there are unpaid claims for work done on projects by prime contractor or by those in lower echelons of supply of labor or materials. It is these unpaid claims that are the subject of this Article.

Construction lenders who are in contract privity only with developers do not see themselves as contractually involved with these other claimants. Lenders ordinarily take the position that payment of a prime contractor is the developer's obligation, an obligation not pertaining to the lender. Suppliers on lower tiers of the contracting pyramid are even more remote from the lenders in the sense of contract privity. Increasingly, however, unpaid claimants are seeking to recover in direct actions against construction lenders. And courts increasingly are upholding these claims. ${ }^{5}$ This Article will examine the extent to which judicial relaxation of a contract privity requirement in numerous jurisdictions has increased the scope of construction lender liability.

Unpaid suppliers of labor or materials usually seek recovery from construction lenders because no effective remedy is available from developers, who often have become hopelessly insolvent. ${ }^{6}$ Moreover, effective mechanics' lien protection may also be nonexistent, as a result of either preperformance waivers or subordination of liens to those of the construction lender's mortgages.

Construction lenders are fully aware at the outset that as the projects proceed there may be unpaid contractors, subcontractors, and materialmen. Therefore, they arrange to have their mortgages the senior liens on the property to be improved. Thus, their se-

5 See infra notes 49-109 and accompanying text.

6 Assuming it was practical to seek recovery from a developer, there would be no privity problem for those with whom the developer dealt directly. In the ordinary developer-prime contractor-subcontractors and materialmen pyramid, however, subcontractors and materialmen, as well as those on lower tiers, lack contract privity with the developer. The basic legal devices for resolving claims in such suits are discussed in this Article. See infra notes 65-126 and accompanying text. For a review of cases in which remote parties have sued a developer or owner, see Gee v. Eberle, 279 Pa. Super. Ct. 101, 115-20, 420 A.2d 1050, 1058-60 (1980). 
curity for advances to the developer cannot be impaired by other liens arising later.

Lenders may also take steps to ensure that those who have supplied labor or materials receive payment for the work done. To minimize risks that would be incurred if construction loan proceeds were simply turned over to a developer, who might dissipate them without paying the prime contractor, some loan agreements provide for payment directly to the prime contractor, or to the developer and prime contractor as.joint payees." A more elaborate scheme sometimes extends further to provide for payments directly to subcontractors and materialmen, normally on the basis of approved vouchers certifying that their respective performances have been satisfactorily completed. ${ }^{8}$ When sophisticated disbursement procedures of this kind are used, construction lenders often deposit the construction loan funds with a disbursement agent-frequently a title insurance company-which then administers the receipt of the vouchers and the distribution of the payments. ${ }^{9}$

Similar protection that is less expensive to administer can be obtained by conditioning payment of construction loan installments

7 The endorsements of all payees are necessary to authorize payment of such a check. See, e.g., Cincinnati Ins. Co. v. First Nat'l Bank, 63 Ohio St. 2d 220, 407 N.E.2d 519 (1980).

8 Several states have statutes designed to avoid diversion of funds by the prime contractor. These statutes designate the payments as trust funds that the prime contractor, as trustee, must pay to those whose work generated the funds. Sanctions against contractors for breach of trust vary from state to state. See J. SWEET, LEGAI Aspects of Archrtecture, Engeneering and the Construction Process 472-73 (2d ed. 1977). Attempts to use these statutes to hold lenders liable to unpaid claimants have failed. See, e.g., Koppers Co. v. Garling \& Langlois, 594 F.2d 1094 (6th Cir. 1979) (applying Michigan law); First Nat'l State Bank of N.J. v. Carlyle House, Inc., 102 N.J. Super. 300, 246 A.2d 22 (Ch. Div. 1968); Caledonia Lumber \& Coal v. Chili Heights Apartments, 70 App. Div. 2d 766, 417 N.Y.S.2d 536 (1979); In re ALB Contracting Co. v. York-Jersey Mortgage Co., 60 App. Div. 2d 989, 401 N.Y.S.2d 934 (1978); Shankle Equip. Co. v. Liberty Nat'l Bank \& Trust Co., 569 P.2d 965 (Okla. 1977); Knight Constr. Co. v. Barnett Mortgage Trust, 572 S.W.2d 381 (Tex. Civ. App. 1978).

Breach of trust and breach of an escrow agreement have been asserted from time to time in states that do not have trust fund legislation; these contentions have been given short shrift. See, e.g., Lummus Supply Co. v. Fidelity Fed. Sav. \& Loan Ass'n, 141 Ga. App. 831, 234 S.E.2d 671 (1977); Koppers Co., 594 F.2d at 1094; Mortgage Assocs., Inc. v. Monona Shores, Inc., 47 Wis. $2 \mathrm{~d}$ 171, 177 N.W.2d 340 (1970).

9 Title insurance is often purchased to insure against any encumbrance being superior to the lien of a construction lender's mortgage. As progress payments are made, the title insurance company is asked to update its policy to protect against intervening liens. See Eagan, Viewpoint of Title Company, in Pracrising Law InstTrute, Construction Lending 335, 338-40 (1973); Healey, The Role of the Title Insurer in Connection with the Making of a Construction Loan, in Practising Law InstTtute, Construction Lending 357, 361-64 (1973); Keenan, supra note 3, at 16-17. 
on presentation of signed receipts of the contractor, subcontractors, or materialmen whose completed work warrants the developer's claim for another progress payment. This scheme requires either that the developer have sufficient cash to pay the suppliers before receiving a pay-out from the construction loan, or that the suppliers involved be persuaded to sign receipts for sums not yet received on the faith that the released loan proceeds will be applied promptly to their claims.

Another way that Ienders minimize the risks of unpaid claimants who later might seek some remedy against them is to require, at the outset, the commitment of a payment bond surety to act if the contractor fails to pay subcontractors or materialmen. Payment bonds are commonly required in construction ventures, whether by law as in public projects or by prudential concern in private projects. ${ }^{10}$ Sureties called upon to perform, however, may turn out to be substituted as the claimants seeking relief from lenders. ${ }^{11}$ If, however, a lender was the beneficiary, or one of the beneficiaries, of the surety contract, an action over would not lie. Lenders seeking this protection, therefore, would be well advised to see that their status as beneficiaries of these secondary obligations is made explicit.

Experienced contractors and suppliers are also aware from the beginning that construction projects are risky ventures. A contractor, if doubtful of a developer's creditworthiness, may have enough bargaining leverage to negotiate for someone to guarantee the developer's performance. Alternatively, and perhaps more realistically, the contractor may bargain for direct payment of construction loan funds as work progresses, so that the developer cannot divert or hold back on payments. Those on lower contracting tiers may be able to insist on a payment bond being obtained, and often are covered by disbursement schemes that assure the flow of funds into the hands of the persons performing the work.

In a great many projects, however, there will not be such protective devices. Contractors, subcontractors, and materialmen, with varying levels of business sophistication, are aware of the role of construction loan commitments and look to that source for eventual payment. Skeptical contractors or suppliers may want to be informed by the developer or by the lender of the size and terms of a loan commitment. If the doubts are serious enough, potential con-

10 Guaranty contracts are also regular aspects of transactions involving thinly capitalized corporations.

11 See, e.g., Fred S. Conrad Constr. Co. v. Continental Assurance Co., 215 So. $2 \mathrm{~d}$ 45 (Fla. Dist. C.t. App. 1968) (performance bond surety subrogated to cause of action of prime contractor against construction lender). 
tractors or suppliers may want more than information; they may seek to be included in some fashion as beneficiaries of a loan commitment. These are the kinds of factual ingredients that make up the grist for subsequent litigation over unpaid claims for work done or for materials supplied to a building project.

Another related set of cases arises out of events occurring in the course of performance when the signals of project failure begin to flash. Contractors and suppliers who have been performing without being paid according to the progress payment schedule, or who are alarmed in other ways, may be concerned about continuing performance in the face of a risk of nonpayment even for work already done. Here again, communications with a construction lender may give rise to claims for relief in court.

A substantial number of decisions have been rendered in favor of unpaid suppliers of labor and materials against construction lenders despite the absence of contract privity. In this Article, we will review those cases and the legal theories employed in determining whether to ignore the contract privity requirement and impose liability.

Before turning to an examination of the existing state of the law, it is well to note that this Article deals primarily with construction projects in the private sector. A quite different pattern of financing and contracting occurs when the owner-developer is a public entity. ${ }^{12}$ Governments do not borrow money for their capital purchases, at least not on a single-project basis, and mortgages are not permitted on government-owned works. A hybrid form of public and private construction has emerged under the National Housing Act. ${ }^{13}$ The special problems created by this blending of public and private resources are addressed briefly below. ${ }^{14}$

12 In construction projects in the public sector, general contractors often obtain loans with repayment secured by assignment of forthcoming payments from the governmental agency. Such arrangements may come within article 9 of the Uniform Commercial Code. Spurlin v. Sloan, 368 S.W.2d 314 (Ky. 1963). Contracts involving the United States are subject to the limitations of the Assignment of Claims Act, 41 U.S.C. $\$ 15$ (1976).

The common requirements of performance and payment bonds in public sector construction projects diminish the possible need of suppliers of labor and materials to look to the construction lender for payment. There are, however, often clashes between sureties and lenders over the retainages or holdbacks payable by the government upon completion of the project. See, e.g., National Shawmut Bank of Boston v. New Amsterdam Cas. Co., 411 F.2d 843 (1st Cir. 1969); Speidel, "Stakeholder" Payments Under Federal Construction Contracts, 47 VA. L. REv. 640 (1961); see also Dauer, Government Contractors, Commercial Banks and Miller Act Bond Sureties-A Question of Priorities, 14 B.C. IND. \& Comar. L. Rev. 943 (1973).

13 See 12 U.S.C. $\$ 1707$ to $1715 z-11$ (1976).

14 See infra text accompanying notes 117-22. 


\section{Traditional Privity Requirements Satisfied}

\section{Typically, construction lenders contract directly with devel-} opers. It is possible, however, for those lenders also to establish contractual relationships with contractors, subcontractors, and materialmen in which the traditional requirements of contract privity are satisfied. Such contractual relationships can be created either before work commences on a project or during the course of performance. Thus, a construction loan agreement might make suppliers of labor or materials third party beneficiaries with power to enforce the lender's commitment. Alternatively, a construction lender might become a guarantor of the developer's obligation to pay the contractor, or of the contractor's obligation to pay a subcontractor. Finally, a lender might independently promise a contractor or supplier that it will be paid, under circumstances that create a right of the contractor or supplier to recover on promissory estoppel. Although these are not the ordinary patterns of relationships between construction lenders and contractors, subcontractors, and materialmen, when the necessary factual elements are found, a relationship based upon contractual privity can be established. ${ }^{15}$

15 Similarly, contractors or suppliers may recover in tort actions against construction lenders. If a construction lender has made a material misrepresentation of fact to a contractor or supplier, such as an overstatement of the balance of a loan commitment, and the contractor or supplier has acted in reliance on that misrepresentation, the elements of an actionable tort may be found. In some circumstances, a duty to use reasonable care in the pay-out of funds may be found to exist for the benefit of contractors or suppliers, and breach of that duty may allow recovery in an action for negligence.

Unpaid contractors and suppliers have sought recovery on these and other legal theories that do not require contract privity. See, e.g., Cook v. Citizens Sav. \& Loan Ass'n, 346 So. $2 \mathrm{~d} 370$ (Miss. 1977). In Cook, a prime contractor recovered from the construction lender on a theory that the lender, in disbursing funds, had a duty to the contractor to take care that the developer-borrower did not dissipate the money. The project involved construction of a pre-engineered steel building. Unlike the other cases discussed in this section, there were no undisbursed loan funds when the work was completed. After the contractor finished erecting the structure, he presented a claim for payment to the lender. The lender subsequently released loan funds to the owner of the building without inquiring whether the owner had paid for the labor and materials. There was no contractual obligation on the part of the lender to pay the contractor directly, and it does not appear that the pay-out to the owner was a departure from the loan agreement. Nevertheless, the Supreme Court of Mississippi held that the contractor could recover from the lender on a negligence theory.

The negligence found in Cook was careless disbursement of funds to a borrower, who diverted the money from the project. There are, of course, other possible factual settings that might produce similar results. For example, a lender might pay out on its loan commitment faster than the terms of the loan agreement provide, without notice to the prime contractor or other suppliers. Acceleration of payments might be agreed to as a good-faith response to a cash-fiow problem of a developer that is experiencing what it hopes is temporary difficulty. The effect of that acceleration, however, might be to conceal for a time that the project is failing, 


\section{A. Third Party Beneficiary Claims}

Unpaid suppliers of labor and materials frequently base claims against undisbursed construction loan funds on the theory that they are third party beneficiaries of the agreements between developers and construction lenders. More precisely, they claim that 'they are beneficiaries of the construction lenders' promises to pay out the full amounts committed. ${ }^{16}$ A number of such claims have been successful in reported decisions. Because the results turn largely on the terms of particular loan agreements, only limited general conclusions are possible.

It is well-settled in the law of contracts that the creation of third-party-beneficiary status occurs only when the two parties negotiating the arrangement intend to confer that status on a third party. ${ }^{17}$ In a number of litigated cases, ${ }^{18}$ that critical element of intent was expressly negated by a clause of the loan agreement. For example, the agreement in R.M. Shoemaker Co: v. Southeastern Pennsylvania Economic Development Corp.; a recent Pennsylvania case involving the construction of a multi-million dollar industrial mall, contained this clause: "No Third-Party Beneficiaries. No part of the Loan will be, at any time, subject or liable to attachment or levy at the suit of any creditor or Borrower, or at the suit

thus inducing suppliers of labor and materials to continue to perform work for which they will not be paid after the loan funds have been totally drawn.

Although unpaid suppliers apparently have not attempted often to recover on a theory of common-law negligence, there are statutory provisions in New York and other states that address the problem of a borrower who diverts funds after receiving payments from a construction lender. See supra note 8.

16 In Koppers Co. v. Garling \& Langlois, 594 F.2d 1094 (6th Cir. 1979) (applying Michigan law), a contractor brought suit against a disbursing agent rather than the lender. For reasons not made clear in the opinion of the court, the contractor conceded that it was not a third party beneficiary of the lender's promise to pay out the construction loan funds, and instead sought to establish that it was a third party beneficiary of the owner's covenant in the loan agreement to use the proceeds of the loan to pay for the costs of construction. Id. 1098 . The Court of Appeals rejected that claim, saying that, even if the contractor could qualify as a third party beneficiary of the owner's promise, such status would allow recovery only against the owner, who was not a defendant. Id. The contractor also claimed to be a third party beneficiary of the agreement by which the lender engaged the disbursing agent to handle the administration of the construction loan. The court held that this common type of principal-agent agreement does not create third-party-beneficiary rights, and that, because the contractor had conceded it had no claim against the principal, there could be no claim against the agent. Id. 1088-99.

17 J. Calamaaru \& J. Perulo, Contracts $\$ 17-2$ (2d ed. 1977); 4 A. Corbin, ConTracts $\$ \$ 776-77$ (1951).

18 These cases are discussed infra at notes 19-20 \& 25-26 and accompanying text. See also Spires v. Hanover Fire Ins. Co., 364 Pa. 52, 56-57, 70 A.2d 828, 830-31 (1950); Hillbrook Apts., Inc. v. Nyce Crete Co., 237 Pa. Super. Ct. 565, 571,352 A.2d 148, 151 (1975). 
of the General Contractor, any subcontractor or materialman, or any of their creditors." ${ }^{19}$ The Pennsylvania Superior Court held that this clause precluded the general contractor's suit. Clauses of this type are apparently an insurmountable obstacle to third-partybeneficiary claims. ${ }^{20}$

A quite different judicial response has occurred when the loan agreement has explicitly stated that the lender must pay the contractor, subcontractors, and materialmen directly. One such clause was presented in two Pennsylvania cases, Clardy v. Barco Construction Co. ${ }^{21}$ and Demharter v. First Federal Savings \& Loan Association, ${ }^{22}$ with varying results. The language of the agreement was:

Now Therefore, it is mutually agreed between the parties hereto that the Association shall:

6. Pay out of the funds to contractors, subcontractors or materialmen, as the Association may elect, for work performed, services rendered, and materials furnished in and about the construction of the building. Such payments shall be made at such times and in whatever amounts the Association may deem expedient, and shall be made according to requisitions approved by a building inspector designated by the Association, which requisition shall be in such form and shall contain such information as the Association may require; it being the intention of the parties hereto that the Association shall be free to make the payments heretofore mentioned in such manner that the Association's security shall at all times be protected. ${ }^{23}$

19275 Pa. Super. Ct. 594, 600, 419 A.2d 60, 63 (1980) (emphasis in original).

20 See Pioneer Plumbing Supply Co. v. Southwest Sav. \& Loan Ass'n, 102 Ariz. 258, 428 P.2d 115 (1967); Gee v. Eberle, 279 Pa. Super. Ct. 101, 420 A.2d 1050 (1980); Knight Constr. Co. v. Barnett Mortgage Trust, 572 S.W.2d 381 (Tex. Civ. App. 1978); see also Ellman, Viewpoint of Lender's Counsel, in Practisinc Law Institute, Constauction Llending 300 (1973).

21205 Pa. Super. Ct. 218, 208 A.2d 793 (1965).

22412 Pa. 142, 194 A.2d 214 (1963).

23 Clardy, $205 \mathrm{~Pa}$. Super. Ct. at $221 \mathrm{n} .1,208$ A.2d at $795 \mathrm{n} .1$ (emphasis in original). The construction loan agreement also provided:

It is expressly understood and agreed, any provisions in this agreement to the contrary notwithstanding:

(G) That the Association shall assume no liability whatsoever to the Owmer, his contractors, sub-contractors and materialmen, or others, except for its malfeasance in the application of the said funds for the purposes hereinbefore recited and shall be fully protected in making any payment upon the faith of any requisition, inspector's certificate or release of lien or other instrument, believed by it to be genuine and to have been duly 
The Pennsylvania Superior Court held in Clardy that the general contractor was a third party beneficiary of the construction loan agreement between the lender and the owner. In addition to relying on paragraph 6 , set out above, the court noted that the general contractor was referred to by name in the loan agreement; indeed, he was a signatory to it. The court did not offer any explanation for the three-party execution of the loan agreement. ${ }^{24}$

In Demharter, an earlier case involving the identical language, the Pennsylvania Supreme Court denied third-party-beneficiary status to subcontractors and materialmen. The court declared that the clause permitted, but did not require, the lender to pay subcontractors or materialmen. ${ }^{25}$ The court said that " $[t]$ he right to pay is vastly different from the duty to pay; and only the latter can be enforced." 26

executed by the proper parties, and the Owner does hereby release and discharge the Association of and from any such liability and hereby further agrees to indemnify and save harmless the said Association of and from any and all liability, damages, costs and expenses which it may sustain by reason of its application of said funds in good faith for the purposes hereinbefore set forth.

Id.

24 Counsel for construction lenders have urged inclusion of the prime contractor as a party to a construction loan agreement in order to obtain from the contractor certain covenants and consents for the benefit of the lender. See Ellman, supra note 20, at 251-59, 310-13 (1973).

25 An unusual aspect of Clardy is that the plaintiff was not the prime contractor, but rather was a subcontractor. Clardy was decided by the Superior Court only two years after the Pennsylvania Supreme Court, in Demharter, had denied thirdparty-beneficiary status to subcontractors under an agreement with the same payment provision. The subcontractor in Clardy avoided the holding of Demharter by first reducing its claim against the prime contractor to judgment; thereafter, the subcontractor, using garnishment in execution of that judgment, asserted the primecontractor's claim against the lender.

26 Demharter, $412 \mathrm{~Pa}$. at 153, $194 \mathrm{~A} .2 \mathrm{~d}$ at 219 (emphasis in original).

The result in Clardy followed from the explicit language of the loan agreement concerning the manner in which the loan funds were to be paid out. In the proper circumstances, the same kind of claim could perhaps be based on an implied term of the agreement. If, by usage of trade, lenders ordinarily pay the prime contractors, subcontractors, or materialmen directly, this prevailing practice might become an implied term of the loan agreement unless expressly negated. Cf. Boyd \& Lovesee Lumber Co. v. Western Pac. Fin. Corp., 44 Cal. App. 3d 460, 118 Cal. Rptr. 699 (1975) (claim that lender, who followed the practice of making direct payment to subcontractors and materialmen, had been negligent in making payments to owner and to prime contractor for materials supplied by claimant). One claimant tried to rely on the American Bankers Association's Mortgage Officer Handbook, which said that it was "good policy" for a lender to require builders to support their requests for advances with affidavits that the subcontractors and materialmen had been paid. The court concluded that the Handbook merely suggested guidelines, which might be disregarded if the lender considered them unsuitable for a particular construction project. First Nat'l State Bank v. Carlyle House, Inc., 102 N.J. Super. 300, 246 A.2d 22 (Ch. Div. 1968), affd, 107 N.J. Super. 389, 258 A.2d 545 (App. Div. 1969), cert. denied, 55 N.J. 316, 261 A.2d 359 (1970). 
The concern of the lenders in Clardy and Demharter, explicitly stated in the terms of the loan agreements, was to protect their security in the property. By reserving the right to pay the contractor, subcontractors, or materialmen, the lenders could take whatever action they thought most expedient to deal with unpaid claimants who might obtain mechanics' liens in the property. Nonetheless, the court in Clardy went beyond this expressed purpose and concluded that the loan agreement gave the prime contractor thirdparty-beneficiary status.

Other contract devices used by lenders to protect their security in the property have also been construed to create third party beneficiaries. One such device is a requirement that the ownerborrower prove that all costs of labor and materials and other expenses had been fully paid as a condition on the lender's duty to pay the final installment, which normally includes the retainages. Two California courts ${ }^{2 t}$ have held that such a term in the loan agreement conferred third-party-beneficiary status on laborers and materialmen. But where the owner-developer had merely covenanted with the lender that it would pay all claims of subcontractors and materialmen, courts have refused to accord third-partybeneficiary status to those parties. ${ }^{28} A$ fortiori, where the lender had been authorized to pay out loan funds to the borrower without concern for the possible diversion of those funds from laborers and materialmen, no third-party-beneficiary rights were established..$^{29}$

27 Ralph C. Sutro Co. v. Paramount Plastering, Inc., 216 Cal. App. 2d 433, 31 Cal. Rptr. 174 (1963); Whiting-Mead Co. v. West Coast Bond \& Mortgage Co., 66 Cal. App. 2d 460, 152 P.2d 629 (1944).

28 See Stephens v. Great S. Sav. \& Loan Ass'n, 421 S.W.2d 332 (Mo. Ct. App. 1967); First Nat'l State Bank v. Carlyle House, Inc., 102 N.J. Super. 300, 246 A.2d 22 (Ch. Div. 1968), aff'd, 107 N.J. Super. 389, 258 A.2d 545 (App. Div. 1969), cert. denied, 55 N.J. 316, 261 A.2d 359 (1970).

In International Paper Co. v. Whitson, 571 F.2d 1133 (10th Cir. 1977), a recent Oklahoma case, the owner of the property being improved had also acted as prime contractor. In obtaining a construction loan, the owner-contractor had given the lender an unconditional, irrevocable letter of credit as assurance that it would perform the contractor's obligations. A federal court of appeals, applying Oklahoma law, held that the parties to this agreement had intended that subcontractors and materialmen would be paid from this source if the owner-contractor defaulted.

29 Irwin v. Murphy, 81 Ariz. 148, 302 P.2d 534 (1956).

The claimant in Irwin also sought recovery on a theory of tortious misrepresentation. The lender at some point had shown the contractor a copy of the construction loan agreement. The contractor alleged fraud in the lender's failure to disclose that the agreement obligated payment to the borrower, upon issuance of an architect's certificate, without regard to whether the owner had paid those who supplied labor and materials. The court held that the meaning of the loan agreement was a question of law, not fact, and that there was no evidence of actionable fraud. See also Urban Syss. Dev. Corp. v. NCNB Mortgage Corp., 513 F.2d 1304 (4th Cir. 1975). 
In another group of cases, third-party-beneficiary protection has been claimed by prime contractors on the basis of their considerable involvement in arranging for the construction loans. This is particularly likely to happen in small projects, such as the construction of a single home or the renovation of an existing residence. An unsophisticated owner, knowing less about construction financing than the builder, may be led by the latter to a lending institution. Under these circumstances, some builders have sought recognition as third party beneficiaries of the loan agreements, even though they were not named in the documents, because the lenders were quite aware from the outset of the tripartite arrangement. In two such cases, ${ }^{30}$ courts have declined to grant relief. In one of them-Winnebago Homes, Inc. v. Sheldon ${ }^{31}$-the Supreme Court of Wisconsin explained that, even if a promise for the benefit of the builder could have been implied from the circumstances, the borrower's default had excused the lender from the obligation to pay the builder, who had no better contract position than the borrower.

Even if the contractor has been mentioned specifically in the loan agreement documents, recovery is not ensured. In L.B. Herbst Corp. v. Northern Illinois Corp. ${ }^{32}$ a 1966 Illinois case, the fixture supplier for an 82-unit townhouse development had received an acceptance letter from the owner-developer which adopted by reference the construction-loan commitment letter issued by the lender to the owner-developer. The Illinois Appellate Court held that the supplier was not a third party beneficiary, and that, even if it were, the evidence did not show that the supplier had satisfactorily performed in conformity with the fixture supply contract.

In Burns v. Washington Savings, ${ }^{33}$ a 1965 Mississippi case, loan commitments for four residences to be constructed by the same builder had been negotiated by the builder, to whom the commitment letters were subsequently addressed. The lender later refused to make the loans to the prospective homeowners; the reason for this refusal was not indicated by the court. The builder sued, alleging that the lender's default had forced him to foreclose on the

30 Apex Siding \& Roofing Co. v. First Fed. Sav, \& Loan Ass'n, 301 P.2d 352 (Okla. 1956); Winnebago Homes, Inc. v. Sheldon, 29 Wis. 2d 692, 139 N.W.2d 606 (1966). Although it denied recovery on a third-party-beneficiary rationale, the Oklahoma court in Apex Siding held in favor of the claimant on the principle of equitable estoppel. The contractor in that case had completed the improvements before the lender disavowed the construction loan commitment.

3129 Wis, $2 d$ at 700,139 N.W.2d at 609.

3299 Ill. App. 2d 101, 241 N.E.2d 125 (1968).

33 251 Miss. 789, 171 So. $2 d 322$ (1965). 
mortgages on the four properties and to sell them at a loss. The Supreme Court of Mississippi held that the builder's close involvement in the negotiation of the commitment letters did not make him a third party beneficiary of the lender's obligations. ${ }^{34}$

Summing up these cases, it appears that the contract doctrine of third party beneficiary can be used successfully in some instances by prime contractors, and by subcontractors and materialmen as well, in enforcement of lenders' obligations in construction loan agreements. The content of the loan agreement is critical in such claims. Some terms that were designed to protect lenders against the problems of unpaid claimants have been construed to give those claimants the right to enforce the loan commitments. But achieving third-party-beneficiary status does not ensure a favorable judgment for the supplier of labor and materials. There may be unsatisfied conditions on the lender's duty that bar recovery despite such status. $^{35}$ Borrower defaults on the loan agreements are likely to excuse lenders from performance in many such cases in which unpaid claimants seek reimbursement. As a few of the cases ${ }^{36}$ discussed above indicate, however, there may be circumstances in which the lender's duty to pay is not excused. In those circumstances, the third-party-beneficiary doctrine may be utilized to obtain relief.

\section{B. Pre-Contract Guaranty of the Developer's Obligation}

In the negotiations leading to the congeries of contracts for a construction project, a prospective supplier of labor or materials might bargain for and receive a guaranty from the lender. Thus, a potential prime contractor, concerned about the creditworthiness of the developer, might agree to do the work only if the developer's obligation to pay the prime contractor was guaranteed by someone more reliable. Similarly, a subcontractor or materialman could bargain for such a three-party arrangement. If the lender should

34 Id. at 798,171 So. $2 d$ at 325.

35 Claimants seeking to enforce construction loan agreements as third party beneficiaries are aided, no doubt, by the practice of drafting these agreements to avoid the dangers of providing for nonobligatory advances. Unless a lender's obligation is fixed, the lender runs the risk that its mortgage security will be subordinated to mechanics' or other liens that have intervened since the mortgage was first recorded. See G. Osborne, Handoook on the Law of Montgages 404-05 (2d ed. 1970). Cf. UnIF. SmMpiffication of Land Transfers Act \$5-209, 14 U.L.A. 209, 307 (1980).

36 See supra text accompanying notes 21-24 \& 27. 
agree to be a guarantor, it would become secondarily liable for the developer's obligations.

A guaranty commitment is theoretically more valuable to the contractor than would be third-party-beneficiary status. Under the latter, a breach by the developer of its obligations to the lender, or other failures of conditions in a construction loan agreement, would excuse the lender from performance pursuant to its loan commitment. If, however, the construction lender had guaranteed payment on the developer's promise to a contractor, material failures in the performance of the loan contract would be irrelevant to the lender's liability as guarantor.

From the reported cases, it would appear that lenders do not often knowingly assume liability as guarantors; however, KleinDickert Oshkosh, Inc. v. Frontier Mortgage Corp., ${ }^{37}$ a 1980 Wisconsin case, was decided against a lender on this theory. The lender insisted that it had not agreed to guarantee the developer's contractual obligation to a contractor. The contractor, however, repeatedly had made clear its demand for a guaranty, and had dealt directly with the lender's representative, who responded with an ambiguous letter to the contractor. The court, under the circumstances, construed that letter as a guaranty.

\section{Obligation Incurred by Lenders in the Course of Performance: Guaranty, Promissory Estoppel, and Misrepresentation Claims}

As a development progresses, evidence may accumulate indicating that the developer is in financial trouble. Its obligations may have gone unpaid too long, mechanics' liens may have been filed against the project, or unforeseen setbacks may have occurred. As the prospect of future payment diminishes, those working on the project or supplying materials may seek additional assurance that they will be paid in due course. One entity to which they might turn for assurance is the construction lender, who also may have a stake in keeping the project from collapsing. From such midperformance communications, unsatisfied suppliers may fashion the elements of claims that the lender promised to pay them, either through guaranty of the developer's obligation or as an independent liability. Lacking consideration in the formal sense, these promises 
could nevertheless be deemed enforceable under the rubric of promissory estoppel. ${ }^{38}$

A close examination of the circumstances surrounding the lender's assurances to the suppliers may reveal that the lender did not explicitly promise performance, but merely made a statement of fact upon which the suppliers relied. In subsequent litigation, unpaid claimants might invoke the doctrine of equitable estoppel to prevent the lender from contesting these facts. This would permit the claimants to recover under an appropriate legal theory, such as a promise to pay out of a fund described by the lender. Alternatively, a lender's misrepresentation of a material fact might give rise to a tort claim if it induces detrimental reliance by a contractor or supplier.

An example of a successful use of equitable estoppel under such circumstances is presented by H.O. Bragg Roofing, Inc. $v$. First Federal Savings \& Loan Association, ${ }^{39}$ a 1964 California decision. The project at issue in that case involved improvement of three residential lots. The owner-developer eventually abandoned all work and left the state, but while work was in progress the roofing contractor had a telephone conversation with a loan department employee of the construction lender. The lender's agent assured the roofer that there were sufficient funds in the building loan accounts to pay for all materials and labor it furnished, and that the roofer need not worry about nonpayment because the checks for roofing work would be issued jointly to the developer and the roofing contractor. The roofing contractor continued his performance without taking action under California's "stop notice" statute 40 to stop further payments from the loan accounts that could jeopardize payment of his claim. When the roofing contractor later sought payment, funds in the loan accounts were insufficient. The trial court held that this evidence was sufficient to estop the lender from denying the existence of the funds, and upheld the claim of the roofing contractor. ${ }^{41}$ The court of appeals affrmed. A similar case ${ }^{42}$ in Washington also was decided in favor of the claimant, although the relief was to subordinate the construction lender's lien in the improved property rather than to allow a monetary claim against the lender.

38 See Restatement (Second) of Contracts $\$ 90$ (Tent. Draft No. 2, 1965);

1A A. Corbin, Contracts $\$ 204$ (1963).

39226 Cal. App. 2d 24, 37 Cal. Rptr. 775 (1964).

10 See infra notes 49-56 and accompanying text.

11226 Cal. App. 2d at 27, 37 Cal. Rptr. at 777.

12 Schweitzer v. Equitable Sav. \& Loan Ass'n, 98 Wash. 139, 167 P. 111 (1917). 
First National State Bank y. Carlyle House, Inc.,8 a 1968 New Jersey case arising out of the collapse of a project to build a 106unit apartment building, illustrates the application of the principle of promissory estoppel. The owner-developer in that case had been in financial straits for the better part of a year as the building proceeded. One subcontractor stopped work with about $\$ 65,000$ due on its contract. Upon hearing that the owner had obtained an additional loan from the construction lender, the subcontractor telephoned the lender. The subcontractor testified that the lender had confirmed the new loan, requested the subcontractor to return to the job, and assured him that he would be paid. . Two other subcontractors testified to similar assurances. The lender's witnesses sharply differed from the subcontractor's witnesses in their recollections of the conversations. A New Jersey court of equity, weighing the conflicting testimony, found on the facts against the claimants. The opinion indicates, however, that the court would have granted relief if the evidence had been more favorable to the claimants.

For an estoppel claim to succeed, the claimant not only must prove that the promise or assertion was made, but also must show that he relied to his detriment on the lender's assertion. If the supplier had already finished his contractual duties before communicating with the lender, $i$ it may be impossible to establish reliance. In Lummus Supply.Co. v. Fidelity Federal Savings \& Loan Association, ${ }^{44}$ a recent Georgia case, a materials supplier obtained a document, signed by the lender's senior vice president, in which the lender agreed to hold in escrow more than $\$ 20,000$ to pay the supplier. This was much stronger evidence than the typical disputed testimony about a telephone conversation with an employee of a lender who may or may not have had authority to bind the lender. Unfortunately for the claimant, the materials had already been supplied when this document was prepared. Moreover, the materialman had acted promptly to perfect a mechanic's lien, thus negating a possible theory of reliance by failure to resort to other available remedies, as in Bragg. The Georgia court held that the lender's promise was unenforceable for lack of consideration.

13102 N.J. Super. 300, 246 A.2d 22 (Ch. Div. 1968), aff'd, 107 N.J. Super. 389, 258 A.2d 545 (App. Div. 1969), cert. denied, 55 N.J. 316, 261 A.2d 359 (1970); accord Mortgage Assocs., Inc. v. Monona Shores, Inc., 47 Wis. 2d 171, 182, 177 N.W.2d 340, 348 (1970) ("The difficulty with this argument on appeal is that the trial court found no such promises were made by Associates . . . "); see also Urban Syss. Dev. Corp. v. NCNB Mortgage Corp., 513 F.2d 1304 (4th Cir. 1975).

14141 Ga. App. 831, 234 S.E.2d 671 (1977). 
In promissory èstoppel cases, as in any suit to enforce a contract, the defendant will succeed if there is a material unsatisfied condition on the disputed promise. In a 1966 Wisconsin case, ${ }^{45}$ for example, part of the court's analysis in rejecting a promissory estoppel claim followed from its conclusion that there was an unfilled condition on the lender's promise that induced the builder to continue performance.

The elements of a claim based on estoppel, whether equitable or promissory, are closely related to the elements of the tort of misrepresentation. For example, if a lender informs a subcontractor that there is $\$ 46,000$ in the construction loan account, when the account contains only $\$ 26,000$, and the subcontractor proceeds in reliance on the lender's statement, the lender might be held liable for tortious misrepresentation. ${ }^{48}$ Other critical misstatements may occur during performance. As a Florida appellate court has stated: "A. construction lender who falsely advises a materialman or subcontractor that the mortgage is not in default must suffer the consequences if further-work and materials are incorporated into the project in reliance thereon." 47 In neither that case nor a later case, however, were the claimants able to satisfy the courts that the requisite facts had been proved. ${ }^{48}$

Estoppel and misrepresentation theories offer relief to unpaid claimants only on the particular facts of each case. Where a lender has made a statement or a promise, and the contractor has changed position in reliance on the statement or promise, a substantial possibility for relief exists.

\section{Statutory Provisions}

\section{A. Stop Notice Statutes}

Several states have adopted statutes that allow subcontractors and materialmen to halt further payments of construction loan funds from the construction lender to a developer. By preventing further disbursements, these claimants preserve funds from which they can seek eventual payment. The protection of these "stop

18 Winnebago Homes, Inc. v. Sheldon, 29 Wis. 2d 692, 139 N.W.2d 606 (1966); see supra text accompanying note 31 .

46 See Klein-Dickert Oshkosh, Inc. v. Frontier Mortgage Corp., 93 Wis. 2d 660, 287 N.W.2d 742 (1980) (dictum).

47 J.G. Plumbing Serv., Inc. v. Coastal Mortgage Co., 329 So: $2 d$ 393, 396 (Fla. Dist. Ct. App.), cert. denied, 339 So. 2d 1169 (Fla. 1976).

18 See Indiana Mortgage \& Realty Investors v. Peacock Constr. Co., 348 So. 2d 59 (Fla. Dist. Ct. App. 1977), cert. denied, 353 So. 2d 677 (Fla. 1979). 
notice" statutes is in addition to the property interests that can be obtained by mechanics' liens. The beneficiaries of these statutes do not include general contractors. Subcontractors and materialmen, however, are given a power to control performance of construction loan agreements without regard to privity of contract.

By both statute 49 and judicial decision, ${ }^{50}$ unpaid suppliers of labor and materials receive special protection in California. In addition to its version of mechanics' lien interest in improved property, ${ }^{51}$ California has had a "stop notice" statute since $1951 . .^{62}$ To invoke the act against a construction lender, a subcontractor or materialman sends a notice of his claim to the lender, together with a bond of one and one-fourth times the claim. ${ }^{53}$ The purpose of the bond is to protect the lender if the claim is not ultimately established as valid. Unless a recorded payment bond exists for the protection of unpaid suppliers of labor or materials, a construction lender, upon receipt of a bonded stop notice, "shall . . . withhold from the borrower or other person to whom it or the owner may be obligated to make payments or advancement out of the construction fund, sufficient money to answer such claim." s4

The California courts have consistently upheld claimants who have met the requirements of the act.55 The California "stop

19 Car. Crv. Code $\$$ 3156-3175, 3264 (West 1974).

0 See infra note 55 and accompanying text.

11 CaL. Crv. Code \$\$ 3109-3154 (West 1974 \& Supp. 1981).

52 Id. \$\$3156-3175.

53 Id. $\$ \$ 3083,3159$. A lender is permitted to ignore a stop notice sent without a bond. See id. $\S 3162$.

of Id. $\$ 3162$.

The California "stop notice" statute is not limited to proceedings against lenders. Unpaid suppliers of labor and materials can also issue "stop notices" to owners. When a "stop notice" is issued to an owner, the claimant need not provide a bond in order to make the notice binding. See Car. Crv. Cone \$3161 (West 1974).

California is not alone in having a "stop notice" statute. Professor Sweet notes that seven other states have similar legislation: Alabama, Indiana, Mississippi; New Jersey, North Carolina, Texas, and Washington. 'J. SwEET, supra note 8, at $\cdot 47 \cdot$; see ArA. Code \$ 35-11-227(b) (1975); IND. CODE ANN. \$32-8-3-9 (Burns 1979); Mrss. Code ANN. \$85-7-181 (1972); N.J. Stat. ANn. \$\$2A:44-77 to -78 (West 1952); N.C. Gen. Stat. \$44A-20 (1976); Tex. Rzv. Grv. Stat. AnN. art. 5463 (Vernon Supp. 1982); WASh. Rev. Code ANN. $\$ \$ 60.04 .110$, .210 (Supp. 1981). Each of these statutes has its own unique provisions. The New Jersey, North Carolina, and Washington statutes apply to both owners and lenders; the remainder apply only to owners. For a discussion of the Washington statute, see Comment, Mechanics" Liens: The "Stop Notice" Comes to Washington, 49.WASE. L. Rev. 685 (1974).

os Hunt, The Stop Notice Revisited, 54 CaL. S.B.J. 24 (1979). 
notice" statute has also been upheld against a contention that it fails to afford procedural due process. ${ }^{.6}$

\section{B. Subordination of Lender's Mortgage}

Under the New York Lien Law, a construction lender is entitled to lien priority over mechanics' liens only if the loan agreement is publicly recorded. ${ }^{57}$ The recorded agreement must disclose "the net sum available to the borrower for the improvement." ${ }^{88}$. A lender who fails to comply with the public notice requirement will have its mortgage subordinated to any mechanics' liens..$^{59}$ As with "stop notice" statutes, the only beneficiaries of this act are subcontractors and materialmen. Because the operative effect of the statute is limited to defining priorities among competing liens in the same property, the act does not directly affect the construction loan agreement. Indirectly, however, the public :recording of these agreements allows any interested contractor, subcontractor, or materials supplier to ascertain the level of financing and to act accordingly.

The New York courts have applied the statute liberally. In HNC Realty Co. v. Bay View Towers Apartments, Inc. ${ }^{60}$ the recorded loan agreement specified that the borrower would provide surety payment bonds for subcontractors and materialmen. The Appellate Division of the New York Supreme Court held that the lender's acquiescence in the contractor's obtaining only a performance bond was a modification of the loan agreement. Because the loan agreement as modified was unrecorded, the lender lost its priority.

Similarly, the publicly recorded loan agreement at issue in Security National Bank v. Village Mall, Inc., ${ }^{61}$ called for a final installment of the construction loan of not less than ten percent of the loan. The court held that the lender lost priority by agreeing, in an unrecorded modification, to reduce the retainage to five percent. The lender in that case lost even though the recorded loan agreement permitted the lender to advance part or all of any in-

${ }^{86}$ See Connolly Dev., Inc. v. Superior Court, 17 Cal. 3d 803, 553 P.2d 637, 132 Cal. Rptr. 477 (1976); appeal dismissed mem., 429 U.S. 1056 (1977).

67 N.Y. LIEN LAW $\$ \$ 13,22$ (McKinney 1966).

$58 I d . \S 22$.

59 Nanuet Nat'l Bank v. Eckerson Terrace, Inc., 47 N.Y.2d 243, 391 N.E.2d 983, 417 N.Y.S.2d 901 (1979); see N.Y. LIEN LAw §13(1) (McKinney 1966).

6064 A.D.2d 417, 409 N.Y.S.2d 774 (App. Div. 1978).

6185 Misc. 2d 771, 382 N.Y.S.2d 882 (Sup. Ct. 1976). 
stallment before it became due, if the lender believed it advisable to do so, and stipulated that any such advance would not constitute a modification of the agreement. ${ }^{62}$ This clause, commonly used in construction loan agreements in New York, did not override the apparent assurance of a large payment in the final installment. A clause permitting the lender to anticipate payments did protect a lender in another case, however, even though it had paid out ninety percent of the proceeds of a construction loan at a time when only fifty percent of the project had been completed. ${ }^{63}$.

Several other states have enacted similar statutory provisions designed, like the New York Lien Law, to protect subcontractors and materialmen. ${ }^{64}$

\section{Nonstatutory Liability In the Absence OF PRIVITY}

Cases in which contractors or suppliers are able to show con: tractual privity with construction lenders involve unusual factual circumstances not normally found in construction transactions. In the more typical transaction, the various parties may be aware of each other's role, but they do not deal with each other. Lenders contract with developers, who in turn contract with prime contractors, and so on down through the tiers of subcontracts and supply contracts. Despite the absence of privity, a number of courts have concluded that some unpaid contractors or suppliers should be granted relief. The theories employed have been the constructive trust and the equitable lien. In most of these cases, courts have purported to be granting equitable liens.

The equitable lien is a particular form of the constructive trust. ${ }^{65}$ Neither the lien nor the trust depends upon an express or

62 Id. at 786,382 N.Y.S.2d at 894.

63 Ulster Sav. Bank v. Total Communities, Inc., 83 Misc. $2 d$ 645, 372 N.Y.S.2d 793 (Sup. Ct. 1975), aff'd on other grounds, 55 A.D.2d 278, 390 N.Y.S.2d 252 (App. Div. 1976), motion to appeal dismissed, 42 .N.Y.2d 805, 398 N.Y.S.2d 1026 (1977); accord Home Fed. Sav. \& Loan Ass'n v. Four Star Heights, Inc., 70 Misc. 2d 118, 333 N.Y.S.2d 334 (Sup. Ct. 1971).

64 Professor Sweet reports that various forms of "protective statutes exist in Michigan, Minnesota, New Jersey, Oklahoma, and Texas. See J. SwEET, supra note 8 , at $472-73$.

65 See Restatement of Restitution $\$ 160,194$ (1937). For cases that have imposed constructive trusts, see, e.g., Ralph C. Sutro Co. v. Paramount Plastering, Inc., 216 Cal. App. 2d 433, 436, 31 Cal. Rptr. 174, 176 (1963); Whiting-Mead Co. v. West Coast Bond \& Mortgage Co., 66 Cal. App. 2d 460, 464, 152 P.2d 629, 63I (1944); Buchanan v. Federal Sav. \& Loan Ass'n, 457 Pa. 135, 151, 320 A.2d 117, 126 (1974). 
an implied-in-fact contract. Moreover, neither is based on the idea of a contract implied-in-law, a traditional basis for certain restitution remedies; rather, both are based upon property concepts. The equitable lien is a kind of nonconsensual security interest in specific property. The constructive trust contemplates that the "trustee" is under a duty, and therefore the equity courts will order him, to convey property to the "beneficiary." Whether or not a claimant can establish the requisite property interest does not necessarily depend upon any contractual analysis. Because property interests can be created without contractual premises, equitable remedies vindicating property interests can operate free of the restrictions of privity that pertain to contractual claims.

The rationale underlying these equitable concepts is consistent with the property character of the remedy. The prototypical equitable lien case is said to arise when a person has made improvements on land that he does not own, and deserves restitution because the owner of the land otherwise will be unjustly enriched. This fact pattern usually occurs when the one making the improvements reasonably believes that he owns or is about to become the owner of the land. To prevent the unjust enrichment, the person who made the improvements is given a lien on the land, with the consequence that the owner cannot convey a clear title until he satisfies that lien.

A constructive trust arises when a person holding title to property is subject to an equitable duty to convey it to another, on the ground that the constructive trustee would be unjustly enriched if he were allowed to retain the property. ${ }^{68}$ In the circumstance of restitution for improvements upon property, the concepts of constructive trust and equitable lien overlap, and the equitable lien is the means by which a constructive trust is made effective. ${ }^{67}$

In the particular context of failed construction projects, with construction lenders disputing with contractors or suppliers, application of these equitable remedies poses serious difficulties. Each of the parties to the dispute has contractual. interests, though not with all of the others. Each participated in the project with the primary expectation that its contractual rights would be satisfied. The inability of contractors or suppliers to obtain. contractually. promised payments from those in privity is the cause of their seeking compensation from a remote party, the construction lender. Lenders, like the other parties, are committed contractually to im-

66 RestateMENT of Restitution $\$ 160$ (1937).

o7 Id. $\$ 170$. 
mediate parties, commonly developers, and the lenders' contract obligations are defined by the terms of those agreements. To transcend the rights and duties arising by contract, a claimant must show that the defendant has been enriched, the amount of the enrichment, that the enrichment is unjust, and a particular property or res that a court of equity can order to be conveyed or subjected to an equitable lien. We will return to these analytic problems after examining some of the cases in which a remedy has been found proper.

Cases involving completed projects are considered first because some courts have indicated that these are the clearest instances of unjust enrichment of construction lenders. When construction projects have not been completed, courts are in greater conflict over whether unjust enrichment can be shown.

\section{A. Completed Projects}

In Anglo-American Savings of Loan Association v. Campbell,,88. an early District of Columbia case involving a five-house development, the developer, who was also the prime contractor, had failed to complete the project. A performance bond surety finished the buildings, but subcontractors and materialmen were left unpaid as a result of the developer-prime contractor's default. Notwithstanding that the project had been completed, the construction lender, with the consent of the developer, withheld $\$ 3,000$ from the final installment of the construction loan commitment. According to the court, this amount was held back "without justification shown in the conditions of the contract." ${ }^{8}$ When the construction lender and the holders of other encumbrances foreclosed on their security interests, the mechanics' liens of the subcontractors and materialmen were rendered worthless. The claimants sued the lender and asked the court to declare a constructive trust on the undisbursed portion of the construction loan. The court held for the claimants.

The court found no contractual theory that would support recovery, but concluded that there were special circumstances justifying equitable relief. The buildings had been completed in accordance with the plans and specifications submitted to the lender when the loan commitment was made. The subcontractors and materialmen knew that there was a construction loan commitment and relied upon it. The lender, on the other hand, was charged with knowledge from the ordinary course of such transactions that

6813 App. D.C. 581 (D.C. Cir. 1898).

69 Id. 602. 
the loan commitment would be a material inducement to subcontractors and materialmen to supply the prime contractor with labor and materials. The court reasoned thusly:

Having, by its conduct, induced or contributed to induce the appellees to contract with [the prime contractor], and with their materials to increase the security for its own debt, it would be inequitable and unjust to permit the association to withhold the money upon which they relied for reimbursement.

Upon these equitable considerations, we conclude that the court did not err in decreeing the enforcement of a constructive trust in favor of the appellees upon the fund withheld from the loan to [the developer]. ${ }^{70}$

An unusual aspect of the Anglo-American Savings case is the court's conclusion that the lender had no right, under its contract with the borrower, to withhold the final installment. Because the performance bond surety had had to complete the project, it is difficult to conclude that all conditions on the lender's commitment had been satisfied. The only condition mentioned in the opinion-completion of the buildings according to the plans and specificationsmay have been satisfied by the surety's performance, but financial defaults by the developer-prime contractor are almost certain to have occurred prior to the due date of the final payment. Nonetheless, by concluding that the lender had acted wrongfully under its commitment contract, the court established the predicate for finding that the lender had been unjustly enriched. The court treated the lender's debt as a fund that it could order to be paid to the claimants by means of a constructive trust.

If unpaid contractors or suppliers could obtain equitable relief only when lenders withheld funds in breach of their loan commitments, few such cases would ever arise. ${ }^{71}$ As we shall see, courts

$70 \mathrm{Id}$. 603-04.

71 For a rare case illustrating the kind of circumstances in which this fact pattern can occur, see Smith v. Anglo-California Trust Co., 205 Cal. 496, 271 P. 898 (1928). In Smith, there had been undisbursed construction loan funds when the project (development of five lots) had been completed. Within a few days after completion, the developer had died. The lender made no claim to the undisbursed funds. There was no indication of borrower default. On appeal, the contestants were the administratrix of the developer's estate and the unpaid suppliers of labor and materials. The court held that the suppliers had an "equity" in the undisbursed loan funds. The court stressed that Smith had not invested his own funds in. the project; the land had been acquired with borrowed money and the buildings had been financed by the construction loan. Since these arrangements were publicly re- 
have not required lender breach of the loan agreement as a necessary element of a claimant's case for equitable relief.

In Pacific Ready Cut Homes, Inc. v. Title Insurance \& Trust Co., ${ }^{72}$ an early California case, the developers-owners completed building an apartment house, but were otherwise in default under the construction loan agreement. The default perhaps consisted of failure to have mechanics' liens on the building removed; but, whatever the reason, the court found that the lender, "as permitted by its loan contract with the owners," 73 had held back a portion of the construction loan and used it to reduce the amount of principal and interest owing. When the owners failed to meet their repayment obligation, the lender moved to foreclose on its mortgage. A materialman, who had sold supplies to the owners, sued to enjoin foreclosure and to impress an equitable lien on the undisbursed construction loan funds. The Supreme Court of California held for the claimant.

The California Supreme Court's decision was influenced to a considerable extent by its finding that the materialman had relied not on the creditworthiness of the owners, but on the existence of a construction loan commitment. Although there were some communications directly between the lender and the materialman, the court did not base its decision on the possibility of a contractual commitment arising from those communications. It concluded, rather, that equitable considerations warranted the result:

The defendant mortgage company, having received the benefit of plaintiff's performance in the form of a completed building and therefore a more valuable security for its note, is not justified in withholding or appropriating to any other use money originally intended to be used to pay for such performance, and relied upon by plaintiff in rendering its performance. ${ }^{74}$

The most recent litigation involving completed projects arose in Florida. In each of three cases, a Florida District Court of Appeal upheld the claim of an unpaid prime contractor to impress an

corded, the court assumed that the suppliers of labor and materials would not have extended credit to Smith without confidence in the payment of the full amount of the construction loan. The court concluded that it would work a grievous wrong to turn over the money to Smith's estate, where it might become charged with the claims of the estate's creditors.

$72216 \mathrm{Cal}$. 447, 14 P.2d 510 (1932).

$73 \mathrm{Id}$. at $448,14 \mathrm{P} .2 \mathrm{~d}$ at 510.

74 Id. at 452,14 P.2d at 512 . 
equitable lien on the undisbursed portion of a construction loan commitment. Each case involved a large scale project in which the developer's: financial planning did not succeed. Upon failure of the developer, the lender in each case had moved to foreclose on the construction loan mortgage and the prime contractor had asserted a counterclaim, seeking to establish its right to an equitable lien.

The first case, Fred S. Conrad Construction Co. $v$. Continental Assurance Co., ${ }^{75}$ arose from a Federal-Housing-Authority-insured housing development undertaken by the Baptist Senior Citizen Foundation, Inc. Prior to completion of the project, the Foundation defaulted in payments due to the construction lender. The lender, however, did not notify either the prime contractor, which continued to work, or the performance bond surety, which eventually finished the project. Upon completion, the lender instituted foreclosure proceedings. The District Court of Appeal held that the prime contractor and the surety had valid claims against the remaining balance of undisbursed loan funds upon which they had had a right to rely for construction work done or to be done.

In two more recent cases, the courts based their decisions more explicitly on an unjust enrichment theory alone; neither court referred to contractor reliance in its opinion. Morgen-Oswood b Associates, Inc. $v$. Continental Mortgage Investors ${ }^{76}$ involved a hotel construction. The owner failed to arrange for permanent financing as required by the construction loan agreement, and the construction lender, declaring the mortgage to be in default, refused to pay the final $\$ 93,000$ due on the loan commitment. The prime contractor had completed the hotel, but its mechanic's lien was subordinate to the construction loan mortgage. The District Court of Appeal, in holding that the general contractor had an equitable lien in the undisbursed loan funds, concluded that "[i]f there ever was a case for imposition of an equitable lien on a particular property, it is this one. ... [The lender] has been unjustly enriched to the extent of approximately $\$ 93,000$, the balance due appellant under the construction contract." 77

The most recent Florida case, Blosam Contractors, Inc. $v$. Republic Mortgage Investors, ${ }^{78}$ involved a 104-unit condominium.

75215 So. 2 d 45 (Fla. Dist. Ct. App. 1968).

76323 So. 2 d 694 (Fla. Dist. Ct. App. 1975).

77 Id. 684-85.

78353 So. 2 d 1225 (Fla. Dist. Ct. App. 1977). 
The construction loan agreement contemplated marketing of some units before the final pay-out, which was expressly conditioned on the developer's selling at least 56 units. The prime contractor was fully aware of the terms of the loan agreement. The developer defaulted before any of the units had been sold, but after the entire project had been built. The District Court of Appeal declared that the prime contractor was entitled to an equitable lien in the undisbursed loan funds:

The 104 completed condominum units are now owned outright by [the lender, as a result of foreclosure of the construction loan mortgage]. [Lender] has received the benefit of its security, as was its right. However, [lender] still holds $\$ 250,000$ that should have gone toward the creation of that security, while [the contractor] has not received its just dues. This is neither right nor just and the most feasible method of remedying the injustice is to impose an equitable lien on the undisbursed proceeds held by [the lender]. ${ }^{79}$

Neither court explicitly noted contractor reliance in upholding the claimant's right to recover. On these factual circumstances, however, there would have been some expectation about construction loan proceeds. In the setting of Morgen-Oswood, a reasonable general contractor building a hotel would not proceed without giving thought to the financing arrangements made by the developer. But whether or not the contractor made any actual inquiry as to the terms of the loan commitment is uncertain. The Blosam Contractors opinion explicitly indicates that the prime contractor in that case had been informed of the precise terms of the loan agreement and had assented to them in an amendment to its contract with the developer. The contractor thus knew of the condition upon the lender's obligation to make its final payment, namely, sale of a certain number of units. Because the condition was unsatisfied and the court nonetheless held for the contractor, it might be said that the court was holding implicitly that reliance on the known terms of the construction loan agreement is not a necessary part of a claimant's case. The court also noted, however, that the developer's failure may have been caused by the lender's foreclosure, and emphasized that the lender's own acts had made satisfaction of the condition on the final pay-out impossible. 


\section{B. Partially Completed Projects}

The courts that have decided such cases are in conflict about the availability of equitable liens where contemplated projects have not been completed.80 The few cases decided to this point have involved both prime contractor and subcontractor plaintiffs, but the latter category understandably predominates. In this group of cases, by definition, the prime contractor had not finished its promised performance. The only parties who could have performed fully are subcontractors, materialmen, and those on lower tiers of the contractual pyramid. If a prime contractor were to seek recovery on a partially finished project, it would have to justify its abandonment of the work, and presumably would seek to do so on the ground of developer default, such as failure to make progress payments due or other material breach of contract.

The Florida courts, which have been quite willing to use an equitable lien theory in completed projects, have insisted on limiting recovery to those situations. ${ }^{81}$ These courts have rejected claims that lenders had been unjustly enriched by foreclosure on partially finished building projects. In J.G. Plumbing Service, Inc. v. Coastal Mortgage Co., ${ }^{82}$ a case arising out of an unfinished condominium development, for example, a Florida District Court of Appeal refused to give an unpaid plumbing subcontractor an equitable lien in undisbursed construction loan funds:

We do not believe that this principle can be extended to a situation where the default occurs before the construction contemplated by the loan agreement has been completed. Under these circumstances, the construction lender is left with the remedy of foreclosing upon a partially completed building. More often than not, the market value of a partially constructed building will be substantially less than the total cost of the labor and material which has already been incorporated into its construction. Under these circumstances, it cannot be said that the mortgagee has been unjustly enriched. To adopt the rule urged by appellant would place upon construction lenders the unwarranted duty of affirmatively keeping all of the subcontractors and materialmen advised of the status of the mortgage and might even discourage a mortgage lender

80 See genesally G. OsBorne, supra note 4, at 754 .

81 Id. 754 n.23.

82329 So. 2 d 393 (Fla. Dist. Ct. App. 1976). 
from working with its mortgagor so as to enable him to correct his default and to complete the job. ${ }^{83}$

A different point of view prevailed, for a brief time at least, in California. In the mid-1960's, three cases in California's First District Court of Appeal involved claimants who had not met the requirements of that state's statutory protection for unpaid subcontractors and materialmen. They were decided, therefore, on a theory of equitable lien. These three cases indicated a tendency among California courts to impose lender liability in the absence of contractual privity with suppliers of labor and materials.

Miller $v$. Mountain View Savings of Loan Association ${ }^{84}$ involved the construction of five small apartment buildings. The court found that the loan agreement had set up an escrow agent to represent suppliers of labor and materials, and held that this arrangement had induced a plumbing contractor to perform in reliance on the construction loan fund. Rejecting any requirement of completion of the whole project, the court said:

In Pacific Ready Cut Homes the lender was expressly denied the right to offset the balance held against the principal of the loan to the detriment of the lien claimant. It is no great step to conclude that such offset should not be allowed even though the building is not complete . . . . The reasoning behind . . . Pacific Ready Cut Homes is as applicable to the claimant putting in the foundation, or the rough plumbing, as it is to the carpenter driving the last spike. All other factors being equal the rights of one contributing to the construction should not depend on the stage thereof at which his contribution was made. ${ }^{85}$

In Miller, the element of unjust enrichment was thought to be manifested by the prompt resale, after foreclosure, of the partially finished development, seemingly at a considerable profit to the lender. When the property was sold by the trustee under the deed of trust, the lender "paid" some $\$ 65,000$, approximately the amount advanced to the borrower. Immediately thereafter, the lender re-

83 Id. 395; accord Giffen Indus., Inc. v. Southeastern Assocs., Inc., 357 So. 2d 217 (Fla. Dist. Ct. App. 1978); Snead Constr. Corp. v. First Fed. Sav. \& Loan Ass'n, 342 So. 2d 517 (Fla. Dist. Ct. App. 1977) (prime contractor as plaintiff).

84 238 Cal. App. $2 d$ 644, 48 Cal. Rptr. 278 (1965).

85 Id. at 664, 48 Cal. Rptr. at 292 (discussing Pacific Ready Cut Homes, Inc. v. Title Ins. \& Trust Co., 216 Cal. 447, 14 P.2d 510 (1932), discussed supra in text at note 72). The court also referred to Smith v. Anglo-Califomia Trust $\mathrm{Co}_{0}, 205$ Cal. 496, 271 P. 898 (1928), discussed supra in note 71. 
sold the property for over $\$ 76,000$, realizing what the court called a "profit" of about $\$ 11,000$. Thus, the court in Miller had rather persuasive evidence, in the resale price, that the value of the partially completed development was greater than the debt owed to the lender which had bought the property in foreclosure proceedings for the latter amount.

McBain v. Santa Clara Savings \& Loan Association, ${ }^{86}$ the second case in California's First District, elaborated on the decision in Miller. The project involved was a residence, and the developer also had served as prime contractor. Claimants were various subcontractors and materialmen who had been left unpaid when the developer abandoned the partially completed project. Unlike Miller, the loan funds had not been transferred to an escrow agent. Moreover, the various claimants had had only vague information about the developer's agreement with the lender, and all of that information had come from the developer. The Court of Appeal held that this was a sufficient factual base to establish that the claimants had relied on payment from the loan commitment:

[A]n equitable lien may be imposed on the fund if either the borrower or the lender induced persons in the position of appellants [to rely on the loan fund for payment]. . . .

... [W] here suppliers of labor or materials have been induced to rely on the loan fund by either the borrower or the lender, their equitable liens on the fund should have priority over the claims of both of such last mentioned persons to the fund. ${ }^{87}$

The Court of Appeal concluded that, if the lender had had any deficiency claim against the developer following sale on foreclosure of the mortgage, that deficiency would be subordinated to the equitable claimants.

Doud Lumber Co. v. Guaranty Savings \& Loan Association, ${ }^{88}$ the third First District case, arose from the claim of a supplier of materials to a prime contractor building an apartment house. Prior to the beginning of the project, the prime contractor had been in arrears in payments to the materialman for previous purchases. At the outset, therefore, the materialman ascertained from the prime contractor that the developer had obtained a construction loan com-

86241 Cal. App. 2d 829, 51 Cal. Rptr. 78 (1966).

$87 \mathrm{Id}$. at $841,51 \mathrm{Cal}$. Rptr. at 86 (emphasis in original).

s8 254 Cal. App. 2d 585, 60 Cal. Rptr. 94 (1967). 
mitment, and was given the name of the lender. Satisfied with this information from this source, the supplier made deliveries for the project. Later, when payments were not forthcoming, the supplier contacted the lender directly for the first time. The lender replied that funds were flowing slowly because of the payment schedule in the loan agreement, and that nothing more could be done. Thereafter, when the developer defaulted on its obligation to make its first payment to the lender, the lender moved to foreclose on its mortgage. The developer owed the lender about $\$ 74,500$ when foreclosure occurred. After foreclosing, the lender resold the property for $\$ 81,000$. On these facts, the materialman sought an equitable lien in the undisbursed portion of the construction loan commitment. $^{80}$

The trial court held that the claimant had neither relied upon nor been materially induced by the loan agreement between the lender and the developer, and that the lender had not been unconscionably enriched by foreclosing. ${ }^{90}$ On appeal, the District Court of Appeal reversed, holding as a matter of law that the mere existence of a loan agreement and an arrangement for progress payments therefrom constituted a material inducement to a supplier to make deliveries to the project on credit.91 The court also determined that the lender had been considerably enriched at the expense of the materials supplier, whose goods had increased the value of the structure and made the "profit" possible.92

One possible justification for the courts' actions in these cases is that they allowed claimants to recover for the value that they had contributed to the property, thereby enhancing the security of the construction lenders. This rationale was acknowledged in Miller, ${ }^{93}$ but the court also recognized that, as a practical matter, a partially completed project may not have increased enough in value to cover the cost of the supplies and labor incorporated into it.94 This was

${ }^{89} \mathrm{Id}$. at 586-88, $60 \mathrm{Cal}$ Rptr. at 95-96.

$90 \mathrm{Id}$. at 588, $60 \mathrm{Cal}$. Rptr. at 96.

91 Id. at 591, $60 \mathrm{Cal}$. Rptr. at 97-98.

92 Id. at $592,60 \mathrm{Cal}$. Rptr. at 98.

93 See 238 Cal. App. 2d at 659, 48 Cal. Rptr. at 288.

94 Id. at 659 \& n.7, $48 \mathrm{Cal}$. Rptr. at 288 \& n.7. In this footnote, the court included a number of calculations seemingly intended to show that the value of a partially finished building may be different from the value of the labor and supplies contributed to the work up to that point. The first calculation contrasted the trial court's finding of the value of the plumbing work in place with the differential between the subcontract price and the actual costs of completion. Subcontract price less cost of completion might be indicative of the value of the unfinished work in some circumstances, but it was undercut here by evidence that inflation and vandalism 
the argument that had persuaded the Florida courts to confine relief to completed projects, but it did not deter the California courts. Once the point was noted in Miller, the opinion never mentioned it again.

Both the Miller and Doud Lumber Co. decisions seem to have been influenced by the conclusion that the lenders, who had resold the partially completed buildings after foreclosure, had made a "profit," in the sense that their receipts on resale exceeded the amounts they paid to buy the properties on foreclosure. This element was lacking in McBain, in which, apparently, no resale had occurred.95 The opinion in Doud Lumber Co. states that the "profit" had been made at the expense of the unpaid material supplier,, 98 but this seems to ignore the possibility that the "profit" may have been the result of imperfections in the public sale mechanism of foreclosure, which would have taken place even if the materialman had been paid in full. If so, the "profit" would not have been the result of the nonpayment of the materialman.

In Miller, the court offered a rationale that went beyond allowing suppliers of labor and materials to recover for having increased a building's value. The court considered the power of lenders to reduce the risk to other parties of going unpaid for their labor or materials:

$[T]$ here are strong reasons of policy to require the commercial lenders to police the speculative building industry by penalizing the lender if the project fails. . . . It leaves open to the lender [possible] protection through the requirement of a completion bond. . . . It is also suggested that the lender, in addition to inspecting physical progress

after the work had stopped had driven up the actual costs of completion when work had resumed.

The second calculation used by the court included all work done, not only the labor and materials provided by the subcontractor claimant. This calculation began with the resale price obtained by the lender after foreclosing, from which the court deducted the price paid by the developer for the land. The difference, presumably, was indicative of the value of the partially completed building. The figure was then contrasted with the total of (1) the amount advanced by the construction lender, (2) the amount of the unpaid claims, and (3) the (unstated) amount of the owner's investment. The total of these three was larger than the figure derived for the building value. This calculation, like the first, is unsatisfactory, because it assumes that one subcontractor's work is no more or less valuable than that of other suppliers of labor and materials. More fundamentally, this calculation assumes that the value of work equals the amounts paid for it and that none of the lender's advances and the owner's investment was diverted from the project.

95 See 241 Cal. App. $2 d$ at 833,51 Cal. Rptr. at 81.

80 254 Cal. App. $2 \mathrm{~d}$ at 592, 60 Cal. Rptr. at 98. 
. of the work, call for receipted bills, or issue joint checks and use other fiscal controls to insure that payments are properly applied. ${ }^{97}$

The court appears to have envisioned the risk of diversion of funds by developers, and possibly by prime contractors as well, as the stspeculative" aspect of the building industry. The kinds of policing suggested would prevent or inhibit diversion of funds intended by a lender eventually to reach subcontractors and materialmen, but diversion of construction loan proceeds is only one possible cause of failure of subcontractors and materialmen to be paid.

The California courts did not develop a satisfactory rationale for their view in these cases. Whether a more fully articulated position would have emerged in later cases cannot be known, because the California legislature snuffed out the possibility by passing a statute ${ }^{28}$ prohibiting any further use of the theory of equitable lien to compensate parties in building projects. ${ }^{99}$

The most important equitable lien case involving a partially completed project is Gee $v$. Eberle, ${ }^{100}$ a 1980 decision by the Pennsylvania Superior Court. In that case, the developers lost a major prospective tenant during construction of a shopping center. The commitment of the construction lender apparently had been made conditional upon the status of rental contracts; withdrawal of this tenant led the lender to reduce its commitment from $\$ 1,350,000$ to $\$ 1,100,000$. This change, perhaps coupled with other financial problems, led to the developer's defaulting on interest payments due to the lender. Notwithstanding the defaults, the lender continued to make advances on the construction loan commitment for several months, and work continued. After the lender had paid out slightly over $\$ 1,000,000$, work stopped with the shopping center still unfinished. Thereafter, the lender paid in excess of $\$ 200,000$ to substantially complete the project. The lender later foreclosed on the mortgage securing the construction loan and bought the property for $\$ 500,000$.

97238 Cal. App. 2d at 658-59, 48 Cal. Rptr. at 288.

98 CAL. Crv. Code $\$ 3264$ (West 1974).

99 For an analysis of this legislation, which was passed in 1967, see Gutierrez, California Civil Code Section 3264 and the Ghost of the Equitable Lien, 30 HASTINGS L.J. 493, 514-21 (1979). A recent determined effort to find some weakness in the preclusiveness of section 3264 totally failed. See Pankow Constr. Co. v. Advance Mortgage Corp., 618 F.2d 611 (9th Cir. 1980).

100279 Pa. Super. Ct. 101, 420 A.2d 1050 (1980). 
Unpaid subcontractors filed suit in equity against the construction lender. The claimants contended that they were entitled to payment out of the difference between the original loan commitment- $\$ 1,350,000$-and the amount actually advanced by the lender-slightly over $\$ 1,000,000$. Claimants maintained that the lender should be declared a constructive trustee of the unexpended loan funds, or alternatively that they should be held to have an equitable lien upon the funds. From denial of relief in the trial court, the subcontractors appealed.101

The Superior Court held for the subcontractor appellants. In the posture of the case, this required remand for trial, and the appellate court's opinion thus sought only to lay down the legal standards for the trial court to apply in subsequent proceedings. In the course of doing that, Judge Spaeth canvassed the principal issues presented by the use of equitable restitution remedies in this context. The opinion is a major contribution to the legal analysis of this area. ${ }^{102}$

On the fundamental issue of the extent of lender enrichment, the court began with the principle that a lender is not enriched unjustly if it has paid for the work done. Bound by its own 1979

101 One subcontractor prevailed in the trial court and was not party to the appeal. Apparently, the trial court's judgment in favor of the subcontractor was based upon its direct contact with the lender. The opinion of the Superior Court indicates that the subcontractor prevailed because it showed that it had relied upon the lender's assurances of financing. Gee, 279 Pa. Super. Ct. at 109, 420 A.2d at 1055. The Superior Court concluded that a claim for equitable relief exists when a contractor has relied upon assurances of "adequate financing," but that these assurances must have come from the lender itself. Id. at 123-25, $420 \mathrm{A.2d}$ at 1062-63. The court referred to this as a "reliance theory" of recovery. Id. at 125, 420 A.2d at 1063. Without more factual information concerning the nature of the assurances of financing, it is difficult to determine whether the court went beyond the theories of guaranty and promissory estoppel discussed supra in text accompanying notes 37-48.

102 The opinion also discusses at length the related problem of subcontractors and materialmen seeking recovery from the developer-owner when they have not been paid by the prime contractor. Gee, 279 Pa. Super. Ct. at 114-20, $420 \mathrm{~A} .2 \mathrm{~d}$ at 1057-60. The court considered this relevant because the lender, by foreclosing and purchasing the property, had become owner. The court reviewed the case law involving subcontractor claims and concluded that cases denying an equitable restitution remedy had required proof of one or more of three elements: (I) that an owner had engaged in wrongdoing or misrepresentation; (2) that a subcontractor had exhausted a statutory or contractual remedy, and (3) that there was some sort of direct contractual relationship between the subcontractor and the owner. Id. at 117, $420 \mathrm{~A} .2 \mathrm{~d}$ at 1059 . The court concluded that each of these requirements is inappropriate. Id. at $117-19,420 \mathrm{~A} .2 \mathrm{~d}$ at $1059-60$. With respect to the last element, the privity requirement, the court concluded: "The cases imposing this requirement seem to us to ignore the fact that the essence of the doctrine of unjust enrichment is that there is no direct relationship between the parties." Id. at 119, 420 A.2d at 1060 . 
decision ${ }^{103}$ in a similar factual setting, the court held that when a lender makes a construction loan advance on the basis of progress in the work, it has "paid for" that work even though the payments do not reach the subcontractor whose supply of labor and materials , constituted the evidence of progress. The court observed that loan :advances against progress in the work might not be paid out at $: 100 \%$ of the value of the work accomplished; and indicated that, ato the extent that advances represent less than full value, a sub"Contractor might have a claim that the lender had been unjustly -enriched. In the course of this analysis, the court rejected any notion that a lender is unjustly enriched if it fails to police the -distribution of loan funds to ensure that they are not diverted from the project after coming into the control of the developer.

The court also addressed one of the most troublesome issues in equitable lien suits: proof of the amount of enrichment. The court apparently would limit proof of enrichment to situations in which a lender has foreclosed on its mortgage and purchased the property at the sheriff's sale. ${ }^{104}$ How the amount of enrichment might be shown after lender foreclosure was left quite open by the court, which said that a claimant must show "that in some manner the lender's return at the sheriff's sale was enhanced because of the subcontractor's work." ${ }^{105}$ The court declared that proof of a differential between the purchase price in the sheriff's sale and the subsequent resale price was relevant but not conclusive evidence of enrichment. ${ }^{106}$

The court took note of the decisions in other states concerning the difficulty of proving enrichment when a construction project has been stopped before completion. Because the lender in Gee had virtually completed construction before the sheriff's sale, the court declared that it did not have to choose between the Florida view-that no relief is possible in partially completed projects-and the opposite position of the California courts. The court indicated, however, that it saw no reason why a claimant should necessarily

103 Myers-Macomber Eng'rs v. M.L.W. Constr. Corp., 271 Pa. Super. Ct. 484, 414 A.2d 357 (1979) (discussed in Gee, 279 Pa. Super. Ct. at 112-13, 420 A.2d at 1056-57).

104 The court was compelled to this conclusion by R.M. Shoemaker Co. v. Southeastern Pa. Econ. Dev. Corp., 275 Pa. Super. Ct. 594, 419 A.2d 60 (1980) (discussed in Gee, 279 Pa. Super. Ct. at 114 n.6, 420 A.2d at 1057 n.6).

105 Gee, 279 Pa. Super. Ct. at 113 n.5, 420 A.2d at 1057 n.5.

106 Id. at 122,420 A.2d at 1062 . 
be barred from proving enrichment because a project was unfinished. ${ }^{107}$

Following the accepted view of the nature of the equitable remedies of constructive trust and equitable lien, the court emphasized that the claimant must demonstrate that there is a specific and identifiable property, or res, to which the remedy could apply. Notwithstanding the court's analysis of the nature of possible enrichment of a lender through acquisition of title to a building that had been enhanced in value by an unpaid subcontractor's work, the discussion of the res centered on the unexpended construction loan funds. The court considered three alternative scenarios that could be proven:

[1] that [the lender] originally set up a $\$ 1,350,000$ account for the project and there are sufficient funds remaining in that account to pay the appellants; [2] that the original account had sufficient funds to pay the appellants [when they performed their work] but no longer does; or [3] that the original account was no longer in existence at the time appellants performed their work and any further disbursements made on the project afterwards were in a separate account. ${ }^{108}$

The court evaluated these possibilities and perceived no difficulties arising in connection with either the first or the second scenario. If the requisite res exists or can be shown to have existed at a critical time in the past, a court may grant the equitable remedy. The court viewed the third possibility as "the greatest obstacle" to recovery, ${ }^{109}$ although it expressed doubt that evidence would eventually show this to have occurred in the case at hand.

\section{Further Examination of Equitable Remedies}

The Pennsylvania Superior Court's opinion in Gee v. Eberle, building on the analyses of other courts, is a major attempt to come to grips with the use of the concept of unjust enrichment to provide some remedy to those who have supplied labor and materials to a construction project but remain unpaid. The primary remedy for such claimants, provided by statute, is the mechanic's lien. These cases involve attempts to recover by an equitable remedy where the statutory remedy has failed to satisfy the claimants. Typically,

$107 \mathrm{Id}$. at $113 \mathrm{n} .5,420 \mathrm{~A} .2 \mathrm{~d}$ at $1057 \mathrm{n} .5$.

108 Id. at $121 \mathrm{n} .9,420 \mathrm{~A} .2 \mathrm{~d}$ at $1061 \mathrm{n} .9$.

109 Id. 
mechanics' lien laws leave claimants unsatisfied when one of two conditions exists: either a claimant did not take the steps necessary to perfect a mechanic's lien, or a mechanic's lien was worthless as a practical matter. For present purposes, the latter situation is of primary interest. ${ }^{110}$

Given a statutory. scheme explicitly designed to protect contractors, subcontractors, and materialmen, it is reasonable to ask how that arrangement failed in these cases. The circumstances of the cases do not suggest any significant differences from transactional patterns likely to occur regularly when construction ventures fail, leaving suppliers of labor and materials unpaid. A basic premise underlying mechanics' lien statutes is that the value of the labor and materials is present in the building. How would that value disappear when a construction lender forecloses on its mortgage? The lender's claim is limited to the amount it has advanced to the developer of the project, plus interest and expenses of foreclosure. It would therefore seem reasonable to expect that the proceeds of foreclosure would satisfy all of these debts.

The proceeds of foreclosure sales may be inadequate because foreclosure sales are an inherently flawed way to obtain the full value of the property. Sheriff's. sales are fundamentally different in structure and dynamics from private sales. The former are auctions, with no participation by the seller in setting terms likely to be attractive to a particular buyer. A potential buyer must arrange financing and a host of other matters before the auction, because payment is due almost immediately thereafter. A prospective bidder must therefore do substantial planning before the auction is held, with no assurance of success. Not surprisingly, then, these auction sales seldom realize the same price as a private sale conducted by a seller with the goal of maximizing the return by skillful marketing of the property.

Thus, that junior liens often are not paid from the proceeds of foreclosure sales may be attributable to the nature of the procedure. Any successful bidder in a sheriff's sale may obtain property that can be resold privately for a higher price. It thus may be inappropriate to consider construction lenders who have bought prop-

110 Analysis of the former situation-when a supplier of labor or materials seeks an equitable remedy to avoid the consequence of his failure to perfect a mechanic's lien-would require an inquiry into whether the statutory scheme would be undermined if claimants were allowed relief despite noncompliance with the statutory requirements. Such an inquiry would necessarily involve detailed consideration of mechanics' lien statutes, a subject beyond the scope of this article. 
erties at such sales as having been unjustly enriched at the expense of the unpaid suppliers of labor and materials.

Carrying this point one step further, one might say that those claimants with junior liens could participate in the foreclosure sale to assure that the price is bid up high enough to cover the claims of all lien holders. If such participation would not be feasible-and it probably is not in the typical case ${ }^{111}$-the proper solution would be to seek alteration by statute of the way in which property liens are liquidated, not to provide for occasional, haphazard relief to junior lien holders by equitable remedies against purchasers in foreclosure sales. That problem, in other words, transcends the circumstances of construction projects and includes any transaction in which there are senior and junior liens in property being liquidated by foreclosure processes.

The preceding analysis has ignored one important aspect of these cases: that the claimants were not seeking to obtain relief by realizing on the value in the building. There have been some cases in which a claimant sought in effect to reverse the priority of liens in the structure, so that the construction lender's interest would be subordinated to those of suppliers of labor or materials. ${ }^{112}$ But the claimants' focus in the cases discussed above was to obtain relief from the value in the unexpended loan funds. Cases that have found unjust enrichment of lenders do not explain the crossover from the property supposedly enhanced in value-the building-to the property being subjected to an equitable remedy-the unexpended construction loan funds.

Logically, to the extent that a lender has not paid out on the loan commitment, its mortgage interest in the building would be reduced. To the extent that a lender's lien in the building was reduced, there would be possible excess value to support mechanics' liens. Increasing the debt to be satisfied by the construction loan mortgage would not necessarily have benefited unpaid suppliers of labor or materials. Funds given over to the developer of a troubled construction project might or might not eventually have reached those who had worked on the building. Unless the lender were responsible to oversee distribution of loan funds by the borrower,

111 Persons with claims to be satisfied out of the proceeds of a foreclosure sale can bid up to the total of their claims without having to provide any new money. The amount owing to any supplier of labor or materials is likely to be small in relation to the value of the whole project and, therefore, not sufficient to permit it to outbid large lienholders. Unless a mechanic's lienholder has access to sufficient resources to buy the property, it cannot afford to bid at such levels.

112 See, e.g., Apex Siding \& Roofing Co. v. First Fed. Sav. \& Loan Ass'n, 301 P.2d 352, 355 (Okla. 1956). 
and possibly by lower tiers of contractors, further loan payments by the lender would not necessarily have benefited those claiming relief in court.

A resolution must be sought, therefore, that takes into account, as was central to all of these cases, that the defendant was a construction lender. The essence of the plaintiffs' claims in these cases may be not a property interest in the unexpended loan funds, but rather a contract-based right to enforce the loan commitments. Analysis in terms of the property remedies of equitable lien and constructive trust masks the privity problem that arises with a contract theory, under which lenders would be personally liable.

As the facts of the Gee case well illustrate, pursuit of a res in the construction loan funds is unsatisfying. What claimants were seeking to enforce in Gee was the lender's original commitment. The outcome should not turn on whether the lender created a separate bank account specially for that commitment, nor on whether it had a balance on any given day. ${ }^{113}$ Suppliers of labor and materials are not likely to have any knowledge of the bookkeeping practices of lenders. Rather, it is the commitment itself that matters. Enforcement of that commitment reaches beyond the property concepts of equitable lien and constructive trust.

\section{Contractual Claims Against Construction Lenders}

If contract rights are the real basis for claims aimed at undisbursed loan funds, it is necessary to examine the nature of the contract theories to be applied. One possible line of analysis is to treat construction lenders as more directly connected with those who supply labor or materials.

There are indications in some court decisions that construction lenders are not viewed as merely sources of secured credit for developers, but are seen as more broadly integrated into the risk-taking role of the enterprise. Consider the view expressed recently by the Court of Appeals of New York about the interplay among bank, borrower, and suppliers of labor and materials in a construction project:

113 In Miller v. Mountain View Sav. \& Loan Ass'n, 238 Cal. App. 2d 644, 663, 48 Cal. Rptr. 278, 291 (1965), the court indicated that a lender's turning over of the loan funds to a disbursement agent was significant. Even though a fund is held in escrow by a second party, the escrow agent's freedom to disburse money therefrom would be controlled by the terms of the arrangement. Such terms, presumably, would be set by the lender. If so, the effect could be as much control of payments as would be found if the lender made payments directly. See, e.g., Morgen-Oswood \& Assocs., Inc. v. Continental Mortgage Investors, 323 So. $2 d 684$, 685 (Fla. Dist. Ct. App. 1975). 
The bank's position is pivotal; without its financial support, contractors might be unwilling to risk their resources in a project run by a developer of perhaps questionable. soundness. Frequently, the bank is a working partner in the deal in that it co-ordinates its advances to the developer with the actual progress of the construction; at times, it may even bargain for an option to convert its mortgage into an equity interest. ${ }^{114}$

The New York court's categorization of the lender as a "working. partner" who may later become sole holder of the "equity interest" moves a lender much closer, in a contractual sense, to others dealing with the enterprise.

The California District Court of Appeal has put the matter somewhat differently: "The construction loan substitutes the lender's promised money for the real property which his prior deed of trust generally renders inadequate for any realistic relief." 115 In other words, the original investment by an owner-developer would, absent the construction lender's mortgage, provide a cushion to ensure payment of suppliers of labor and materials. The mechanics' lien works optimally for claimants when the owner of property, in order to protect a significant ownership interest, is compelled to compensate unpaid suppliers of labor or materials.

An example of circumstances in which it is reasonable to collapse a series of what appear to be contract relationships into a single enterprise or entity is found in the quasi-public housing developments authorized by the National Housing Act. ${ }^{116}$ Federal courts have decided a number of cases in which prime contractors have been allowed to recover from the Department of Housing and Urban Development (HUD), even though contractually HUD was several steps removed from the contractors' agreements with the developers.

Section 236 of the National Housing Act ${ }^{117}$ authorizes an unusual hybrid of private and public construction. In form, the major participants in such a venture are private entities: private firms are engaged as prime contractors, private lending institutions provide construction loans, and the owners are ostensibly private

114 Nanuet Nat'l Bank v. Erikson Terrace, Inc., 47 N.Y.2d 243, 248, 391 N.E.2d 983, 986, 417 N.Y.S.2d 901, 904 (1979).

115 Miller v. Mountain View Sav. \& Loan Ass'n, 238 Cal. App. 2d 644, 658, 48 Cal. Rptr. 278, 288 (1965).

116 See 12 U.S.C. $\$ \$ 1707-1715 z-11$ (1976).

11712 U.S.C. $\$ 1715 z-1$ (1976). 
corporations. But these owners in reality are nonprofit, no-asset corporations specially created for purposes of the section 236 projects. Contracting firms are induced to enter into construction contracts with these owners because lenders provide $100 \%$ of the construction costs. Lenders agree to these extraordinary commitments because they are fully insured by the federal government.

The motivating force behind these developments has been HUD. HUD carefully avoids direct dealing with the owners and general contractors, but keeps a tight control on the purse strings. Construction loan funds are not disbursed until a HUD official approves. HUD also can cancel the mortgage insurance. When a project fails, the lender extricates itself by assigning the debt and mortgage to HUD or by foreclosing on the mortgage and delivering title to HUD. By either path, HUD is substituted for the lender. Prime contractors have recovered against HUD in a number of recent cases involving troubled section 236 projects. ${ }^{118}$. In two earlier decisions, courts of appeals held that prime contractors had equitable liens in undisbursed construction loan funds. ${ }^{119}$ The most recent decision in favor of a contractor, however, eschewed the equitable lien remedy and employed, instead, the contract remedy of quantum meruit. The facts and reasoning of that case are worth reviewing.

In S.S. Silberblatt, Inc. v. East Harlem Pilot Block-Building $I$ Housing Development Fund Co.j20 about ninety percent of the work on a 650-unit apartment complex had been finished when building stopped. The lender, relying on the ground that the work had not been finished within the scheduled time, refused to make any further advances on the construction loan. The owner in turn dishonored the contractor's request for a monthly payment, and the contractor suspended work. The ensuing litigation involved the builder and HUD. The government argued that, as assignee under the loan agreement, it was entitled to the remaining loan funds to pay for completion of the project. The contractor denied it was making a claim on a third party beneficiary theory, and did

118 The leading cases allowing recovery are: S.S. Silberblatt, Inc. v. East Harlem Pilot Block-Bldg. I Hous. Dev. Fund Co., 608 F.2d 28 (2d Cir. 1979); Spring Constr. Co. v. Harris, 562 F.2d 933 (4th Cir. 1977); Trans-Bay Eng'rs \& Builders, Inc. v. Hills, 551 F.2d 370 (D.C. Cir. 1976). But see Marcus Garvey Square, Inc. v. Winston Burnett Constr. Co., 595 F.2d 1126 (9th Cir. 1979).

110 Trans-Bay Eng'rs \& Builders, Inc. v. Hills, 551 F.2d 370, 381 (D.C. Cir. 1976); Spring Constr. Co. v. Harris, 562 F.2d 933, 938 (4th Cir. 1977). The courts also relied upon third-party-beneficiary concepts.

120608 F.2d 28 (2d Cir. 1979). 
not seek an equitable lien in the retainages and undisbursed loan funds. Rather, the contractor contended, and the court of appeals agreed, that the fundamental claim in cases of this kind is unjust enrichment, for which an equitable lien is one, but not the exclusive, remedy. The contractor sought to recover in quantum meruit. The advantage of that remedy over an equitable lien (and over a third-party-beneficiary claim) is that it permits possible recovery of an amount greater than the retainages and undisbursed loan funds.

The court of appeals explained its use of quantum meruit in favor of the unpaid contractor: "An equitable lien represents but one of several methods which courts in law and equity have devised to remedy unjust enrichment ...."121 Accordingly, the court held that:

[T] he availability of a remedy to appellant is not dependent upon the existence of undisbursed loan proceeds as a res that may be subject to an equitable lien. If appellant should succeed at trial in establishing its claim of unjust enrichment, it would be awarded a judgment for the amount owed ... , and the court, in the exercise of its broad equity power, could grant such restitutionary relief as might be equitable under the circumstances. ${ }^{122}$

In the circumstances of these federal cases, once one looks behind the facade of formal contract relations among a nominal developer, a lender, and HUD, it is reasonable to conclude that the real developer included HUD. Recognition of HUD's role might even allow a prime contractor to enforce against HUD the rights created in the contract between the contractor and the nominal developer. This could be done, if a claimant so chose, in quantum meruit, but it also could be done by an action for breach of the express contract. Thus, telescoping of the contractual relationships may bring a prime contractor into privity with what had appeared to be a remote party whose function was to insure the construction lender's risk exposure.

Similarly, in entirely private construction projects, it may be possible to justify treatment of a lender as a "working partner" and, hence, as involved in the contractual commitments of a developer. Justification might be sought by examining whether a developer is adequately capitalized. When loan funds provide $100 \%$ of a

121 Id. 38 (citations omitted).

122 Id. 
development's costs, as in the quasi-public housing projects, there is no investment by the developer. Undercapitalization is one of the factors used in piercing the corporate veil to allow contract relief from a shareholder. ${ }^{123}$ It may be that the debt-equity ratio in construction ventures should determine, at least in part, whether recovery may be had from a lender. In the private construction cases discussed in this Article, the opinions do not give a clear enough statement of the relevant facts to permit detailed review. Although there are suggestions that some courts may have been influenced by the minimal investments of developers, ${ }^{124}$ these cases do not provide a basis for further inquiry into the particular sets of circumstances that would warrant treatment of a construction lender as a "working partner" of a developer.

Alignment of a construction lender as the "working partner" of a developer, when justified, does provide a theoretical basis for resolving some of the questions of contract privity raised by contract claims against construction lenders. A useful analogy can be drawn from the law of partnerships, under which every partner is liable for the contractual obligations undertaken by any partner for the partnership entity. Perhaps an even more apt analogy might be found in the law of joint ventures. The analogy can be extended further by using the concept of the limited partnership to represent the limited role of construction lenders, who ordinarily do not participate in the risks of profit or loss in the projects and whose maximum financial exposure is expressed by the amount of the loan commitments.

The partnership or joint venture analogy is advantageous for those who have dealt directly with an authorized representative of the entity. Thus, persons who have contracted with the developer might be able to establish that they are also in contract privity with the construction lender. Normally, only the prime contractor could make such a claim. In some projects, however, developers act as.

123 Gallagher v. Reconco Builders, Inc., 91 Ill. App. 3d 999, 415 N.E.2d 560 (1980); Yacker v. Weiner, 109 N.J. Super. 351, 263 A.2d 188 (Ch. Div. 1970), aff'd, 114 N.J. Super. 526, 277 A.2d 417 (App. Div. 1971). See generally H. Barrantine, Ballantine on Corporations $\$ \S 129,130$ (rev. ed. 1946); I W. Fletcher, Cyclopedia of the Law of Pruvate Corporations $\$ \$ 41,44$ (perm. rev. ed. 1974); Hamilton, The Corporate Entity, 49 TEx. L. REv. 979 (1971); Comment, Disregarding the Corporate Entity: Contract Claims, 28 Omо Sr. L.J. 441 (1967).

124 See, e.g., Pacific Ready Cut Homes, Inc. v. Title Ins. \& Trust Co., 216. Cal. 447, 451, 14 P.2d 510, 511 (1932) (owner insolvent when venture began); McBain v. Santa Clara Sav. \& Loan Ass'n, 241 Cal. App. 2d 829, 841, 51 Cal. Rptr. 78, 86 (1966) (appellants faced the precarious situation of contributing labor and materials to property heavily encumbered by both a purchase money loan and a construction loan). 
their own prime contractors and deal directly with suppliers of labor and materials. All such suppliers could enforce their contract claims against the entity, although with liability limited to the lender's maximum exposure in any suit against a lender.

It is fortuitous, perhaps, that most of the cases in which courts have granted relief to unpaid claimants have involved only what might be called a single privity problem. These claimants were, by ordinary contract principles, in privity with the developers, and the one privity problem thus was to find justification for pursuing the claims against the remote lenders. ${ }^{125}$ Only two of the cases in which claimants were allowed to recover involved double privity problems, in the sense that the claimants had no contract privity with either the developer or the construction lender. ${ }^{126}$

\section{ConCLUSION}

The idea that construction lenders can be held liable to suppliers of labor and materials has received enough support from courts and legislatures to become respectable. Some of the judicial developments, however, still lack an adequately principled rationale.

125 See Pacific Ready Cut Homes, Inc. v. Title Ins. \& Trust Co., 216 Cal. 447, 14 P.2d 510 (1932); McBain v. Santa Clara Sav. \& Loan Ass'n, 241 Cal. App. $2 d$ 829, 51 Cal. Rptr. 78 (1966); Miller v. Mountain View Sav. \& Loan Ass'n, 238 Cal. App. 2d 644, 48 Cal. Rptr. 278 (1965); Gee v. Eberle, 279 Pa. Super. 101, 420 A.2d 1050 ( 1980 ).

126 The courts' opinions in the two exceptions provide less than adequate information concerning why the prime contractors defaulted in their obligations to the suppliers of labor and materials. The court in Anglo-American Sav. \& Loan Ass'n v. Campbell noted only that the prime contractor had "failed." 13 App. D.C. 581, 586-87 (D.C. Cir. 1898). The second case, Doud Lumber Co. v. Guaranty Sav. \& Loan Ass'n, does not provide even this much information, though the court noted that the materialman and the general contractor had dealt with each other previously, and that the general contractor was in arrears on payments to the supplier from those dealings. $254 \mathrm{Cal}$. App. 2d 585, 587, 60 Cal. Rptr. 94, 95 (1967). (This fact was mentioned to explain the supplier's precontract inquiry into the existence of a construction loan.) With so little factual basis, useful analysis of these decisions is not possible.

In Anglo-American Sav. \& Loan Ass'n, the earliest case to employ the equitable lien remedy, the court concluded that the lender had withheld the final installment of the construction loan without justification under the loan agreement. 13 App. D.C. at 602 . This made it possible to find the lender unjustly enriched by reference to its contract commitment. None of the later cases found that a lender was in breach of its loan commitment.

In Doud Lumber Co., the court declared that the lender, with apparent sophistication in commercial financing, had occupied a privileged, secure, and dominant position in the arrangements, had had full control of the funds, and yet had neglected to protect its position. 254 Cal. App. 2d at 589-90,60 Cal. Rptr. at 97. The court may have meant that the lender should have called for receipted bills, issued checks to joint payees, or used other fiscal controls to insure that payments reached subcontractors and materialmen, see Miller, 238 Cal. App. 2d at 258-59, $48 \mathrm{Cal}$. Rptr. at 288, but there is no basis in the opinion for concluding that such action would be more than a prudent safeguard for a lender's own protection. 
When particular facts show lenders entering into commitments that run to suppliers of labor and materials, whether by direct communication or by third-party-beneficiary contracts, accepted contract doctrines can be applied. When these elements are lacking, some courts have used the restitution remedies of equitable lien or constructive trust in favor of unpaid contractors, subcontractors, and materialmen. These remedies, derived from property concepts, do not fit comfortably with the claims made, which essentially seek to hold construction lenders personally liable under their loan commitments.

An alternative remedial basis, founded on contract principles, may offer a better rationale, at least for the claims of those parties who have dealt with the developer. There may be sound basis in many projects to characterize the construction lender as part of the developer's team, rather than as an independent entity merely supplying secured credit. This may be the most principled path toward establishing the normative standards for construction lender liability, and would meld well with the growing body of contract law that is extending the bounds of traditional privity concepts. 